Revista Eletrônica de Direito Processual - REDP. Volume 16. Julho a dezembro de 2015

Periódico Semestral da Pós-Graduação Stricto Sensu em Direito Processual da UERJ

Patrono: José Carlos Barbosa Moreira. ISSN 1982-7636. pp. 240-281 http://www.e-publicacoes.uerj.br/index.php/redp/index

\title{
APLICAÇÃO DO INCIDENTE DE RESOLUÇÃO DE DEMANDAS \\ REPETITIVAS PARA AS AÇÕES COLETIVAS: UM TERCEIRO CAMINHO \\ PAUTADO NA ISONOMIA ${ }^{1}{ }^{2}$
}

\section{THE APPLICATION OF REPETITIVE PROCEEDINGS TO CLASS ACTIONS: THIRD WAY BASED ON EQUALITY}

Laís Fernandes Almeida

Pós-graduada em Direito Processual pela Universidade Federal de Juiz de Fora/MG.

lais_fernandes_jf@hotmail.com

RESUMO: O presente artigo se propõe a analisar o ditame do art. 976, CPC 2015 que prevê aplicação do incidente de resolução de demandas repetitivas. A adoção deste mecanismo demonstra o apreço pelas decisões uniformes e a necessidade de conter o contingente de causas que obstrui do judiciário e privilegiar a celeridade. $\mathrm{O}$ incidente aplica-se também às demandas coletivas, de tal modo que remedia, mas não repara a injustiça ocasionada pela previsão do art. 16, LACP que cria mecanismo inconstitucional e desprovido de suporte teórico, pelo qual a coisa julgada sobre restrição territorial. $\mathrm{O}$ incidente pode servir de auxílio para melhor delinear os direitos individuais homogêneos e os direitos repetitivos.

PALAVRAS-CHAVE: Igualdade; CPC 2015; incidente de resolução de demandas repetitivas; ação coletiva.

ABSTRACT: The goal of this dissertation is to analyse the new discipline of repetitive demands, brought by art. 976, CPC. The adoption of this mechanism shows the value of iguality in decisions and the urgent need to manage the number of causes which are causing many difficulties for a fast and equal solution. The new mechanism can be apllied to demands similar to class actions and the result is more equality despite of the injustice

\footnotetext{
${ }_{1}^{1}$ Artigo recebido em 16/08/2015 e aprovado em 27/11/2015.

${ }^{2}$ Artigo produzido sob orientação do Prof. Dr. Márcio Carvalho Faria e Profa. Dra. Clarissa Diniz Guedes.
} 
Revista Eletrônica de Direito Processual - REDP. Volume 16. Julho a dezembro de 2015

Periódico Semestral da Pós-Graduação Stricto Sensu em Direito Processual da UERJ

Patrono: José Carlos Barbosa Moreira. ISSN 1982-7636. pp. 240-281 http://www.e-publicacoes.uerj.br/index.php/redp/index

brought by the application of art. 16, LACP, which is against national constitution because restrict res iudicata in a certain territory.

KEYWORDS: Equality; CPC 2015; discipline of repetitive demands; class actions.

SUMÁRIO: 1. Contexto histórico. 1.1. Incidente e a realização de justiça e isonomia. 2. Precedentes. 3. O incidente. 3.1. Da confusão teórica. 3.2. Conceito de demandas repetitivas. 3.3. Grinover: uma visão apurada sobre o direito coletivo. 3.4. Primeiro requisito de aplicação do IRDR: repetição da questão de direito. 3.5. Segundo requisito: risco de ofensa à isonomia e à segurança jurídica. 3.6. Procedimento. 4. Aplicação do incidente. 4.1. A aplicação da tese jurídica comum. 4.2. A distinção entre ação coletiva e o IRDR. 5. Tutela Coletiva. 5.1. Coisa julgada na tutela coletiva. 5.2. Um direito para cada lugar? 5.3. Precedente X Coisa julgada. 6. Conclusão. 7. Referências bibliográficas.

\section{CONTEXTO HISTÓRICO}

Inicialmente, o processo era marcado por um perfil individualista, influenciado pelo liberalismo; as regras do CPC/73 foram estruturadas para resolver conflitos individuais. Este posicionamento se revelou inadequado para a resolução dos conflitos atuais, que muitas vezes repetem situações pessoais idênticas, que tramitam paralelamente a despeito da coincidência das ações quanto ao objeto e na razão de seu ajuizamento.

A atividade econômica moderna, em virtude do desenvolvimento do sistema de produção e distribuição seriada de bens levou à insuficiência do Judiciário para atender ao crescente número de feitos repetitivos. As regras do $\mathrm{CPC} / 73$ se revelaram inaptas, de modo que se passou a adotar mecanismos de tutela de direitos coletivos.

Leonardo da Cunha (2011, p. 257) argumenta que estas ações coletivas não são capazes de abranger todas as situações repetitivas. Primeiro porque não há legitimados suficientes para tratar de todas as situações massificadas. Segundo, ações coletivas não são admitidas em alguns casos, como para tratar de matéria tributária e FGTS, por exemplo, por expressa exclusão feita pela Medida Provisória 2.180-35/2001. Terceiro, porque o regime aplicável à "coisa julgada coletiva contribui para que as questões repetitivas não sejam definitivamente solucionadas", nos dizeres de Cunha (2011, p. 258), já que, em sendo 
Revista Eletrônica de Direito Processual - REDP. Volume 16. Julho a dezembro de 2015

Periódico Semestral da Pós-Graduação Stricto Sensu em Direito Processual da UERJ

Patrono: José Carlos Barbosa Moreira. ISSN 1982-7636. pp. 240-281 http://www.e-publicacoes.uerj.br/index.php/redp/index

julgado procedente o pedido, ou improcedente por instrução insuficiente, haverá coisa julgada para os legitimados coletivos mas poderão ser propostas demandas individuais para proteger o direito individual dos sujeitos; julgado improcedente por falta de provas, não ocorre coisa julgada, de modo que qualquer legitimado coletivo poderá repropor a demanda e ainda serão possíveis as demandas individuais. Ou seja, havendo improcedência, por qualquer razão, não fica vedado ajuizamento de ação individual ${ }^{3}$.

$\mathrm{O}$ autor, contudo, esqueceu-se de que nem toda demanda repetitiva é direito coletivo, o que será objeto de estudo mais à frente. Assim, o problema relativo ao volume de trabalho ocasionado pelas demandas repetitivas, muito recorrentes atualmente, não poderia de qualquer sorte ser resolvido pelos mecanismos de tutela coletiva, porque nem todo direito repetido pode ser tratado em ação coletiva - nem todo direito repetido é "coletivizável".

Os direitos difusos e coletivos strictu sensu não podem ser protegidos por demandas individuais; o titular de direito difuso não pode sequer ajuizar uma ação individual. Assim, o problema gira em torno dos direitos individuais homogêneos, dada a dificuldade de sua delineação e considerando que poderão ser tratados tanto por ação individual quanto por ação coletiva.

Ademais, Leonardo da Cunha (2011, p. 261) destaca que a restrição da eficácia subjetiva da coisa julgada em ação coletiva, prevista no art. 16 da lei 7.347/1985 e pelo art. 2-A da Lei 9494/1997 “impõe uma limitação territorial e uma indevida fragmentação dos litígios", contrariando as razões de ser da tutela coletiva, que visa a concentrar a discussão em uma única causa e decidi-la de modo uniforme. Este aspecto será analisado mais detidamente.

A preocupação com a efetividade trouxe consigo a necessidade de os trâmites processuais se adaptarem ao fenômeno de massificação de demandas. $\mathrm{O}$ volume representou um grande entrave não só à resolução dos litígios massificados como de todos os outros, pela dificuldade em se uniformizar a discussão, concentrar a lide, e contornar os problemas relacionados aos conflitos de competência do art. 16, LACP, de modo que toda a atividade jurisdicional ficou comprometida. Este resultado fica claro quando refletimos sobre a

\footnotetext{
${ }^{3} \mathrm{O}$ argumento mais formal para não indução de litispendência é o de que em uma ação o pedido é coletivo (difuso, coletivo stricto sensu ou individual homogêneo) e, na outra, o pedido é individual. Mas o direito individual homogêneo é, teoricamente, divisível, apesar da repercussão social que marca-o como direito coletivo. Este posicionamento, pensando na proteção substancial do direito, também prestigia o princípio da inafastabilidade da tutela jurisdicional, art. $5^{\circ}, \mathrm{XXXV}, \mathrm{CRFB}$. O primeiro argumento é explicado por Costa e Lascala (2010, p. 4).
} 
Revista Eletrônica de Direito Processual - REDP. Volume 16. Julho a dezembro de 2015

Periódico Semestral da Pós-Graduação Stricto Sensu em Direito Processual da UERJ

Patrono: José Carlos Barbosa Moreira. ISSN 1982-7636. pp. 240-281 http://www.e-publicacoes.uerj.br/index.php/redp/index

impressão atual do homem médio sobre o Judiciário: uma máquina muito pesada, nem sempre coesa (por admitir interpretações e decisões opostas) e que "não vai para frente".

A massificação deve ser estudada observando que os interesses massificados se dividem em dois modelos distintos de tutela destes interesses: os coletivos e os individuais repetitivos. Analisar-se-á ao longo do trabalho as interações e a tratativa dispendida pelo CPC/2015, que alteraram a dinâmica entre estes dois modelos, e suas implicações práticas.

\subsection{Incidente e a realização de justiça e isonomia}

Renato Xavier da Silveira Rosa traz a importância do movimento de generalização do caso individual, que delinea uma nova onda de evolução do processo marcado pela necessidade de uniformização:

Zaccaria expõe a ideia de que a jurisprudência representa um movimento de passagem de normas individuais a gerais, dotadas de força vinculante (ainda que como meros precedentes persuasivos repetidos, em que sua reiteração constitua um costume que o torne fonte de direito). (...) $\mathrm{O}$ movimento de generalização do caso individual é, de tal modo, nada mais que a interpretação de uma narrativa passada para dela extrair os elementos essenciais ao raciocínio lógico-comparativo com uma narrativa diferente (que é o caso presente a ser julgado). (ROSA, 2013, p. 66).

O precedente sempre atua como paradigma para os próximos casos. A valorização dos precedentes não é um movimento exclusivo dos sistemas de common law, porque se configura em verdadeira medida de justiça, como explicitado por Cunha (2012, p. 355). Em regra, onde houver decisão judicial, há precedente, pois “a ideia segundo a qual os casos símiles devem ser decididos de modo semelhante é um princípio de justiça reconhecido no âmbito de toda a tradição jurídica ocidental” (grifo nosso), palavras de Mattei (2004 apud CUNHA, 2012, p. 356).

A distinção está, na verdade, em como se utiliza o precedente: nos países de common law o instituto típico é o stare decisis, que indica uma obrigação jurídica de que, nos casos 
Revista Eletrônica de Direito Processual - REDP. Volume 16. Julho a dezembro de 2015

Periódico Semestral da Pós-Graduação Stricto Sensu em Direito Processual da UERJ

Patrono: José Carlos Barbosa Moreira. ISSN 1982-7636. pp. 240-281 http://www.e-publicacoes.uerj.br/index.php/redp/index

futuros, não se discorde de certo precedente. Já nos países de civil law, geralmente a força dos precedentes está na ideia de que os órgãos jurisdicionais inferiores não devem deixar de respeitar a interpretação da lei ditada pela corte superior. Na verdade, há algum tempo experimentamos formas mais objetivas de vinculação de precedentes, e o próprio incidente de resolução de demandas repetitivas (IRDR) constitui um exemplo disto.

A generalização do caso individual, de que tratava Zaccaria, representa essa extração da norma jurídica do texto normativo para aplicá-la aos casos semelhantes. Neste movimento se valoriza a função paradigmática que tem a decisão, que será analisada mais à frente, pelo que é natural, pelo nosso entendimento de justiça, que um caso seja ao mesmo tempo norma individual e concreta, mas também geral e abstrata, na medida em que realiza a necessária uniformidade na aplicação das leis.

O sistema de incidente de resolução de demandas repetitivas busca a generalização da norma ao extrair uma tese jurídica geral. As características próprias do incidente talvez dificultem sua classificação dentre os institutos já conhecidos; o que importa atentar é que ele representa uma alteração substancial na sistemática processual como concretização de situação experimentada pela sociedade, mas ainda não "traduzida" normativamente.

\section{PRECEDENTES}

Os precedentes podem ser definidos como uma decisão judicial que tenha aptidão para veicular normas que, a despeito serem individuais e concretas, serão também gerais e abstratas ao serem aplicadas a casos semelhantes, segundo os dizeres de Rosa (2013, p. 28). Pode ser entendido, ainda, como, por Cunha (2012, p. 357) "diretriz a ser seguida no julgamento de futuros casos análogos", assegurando-se tratamento isonômico e previsibilidade.

É composto pelas circunstâncias de fato, e pela tese ou princípio jurídico expresso no fundamento da decisão. A tese, a ratio decidendi, é o que deve ser seguido nas causas semelhantes; é o resultado da aplicação do direito ao caso. "A ratio decidendi identifica-se, não com a decisão do caso concreto, mas com a razão jurídica da decisão, ou seja, com o princípio jurídico que, aplicado aos fatos, determinou aquela particular decisão", como dito por Cunha (2012, p. 358). 
Revista Eletrônica de Direito Processual - REDP. Volume 16. Julho a dezembro de 2015

Periódico Semestral da Pós-Graduação Stricto Sensu em Direito Processual da UERJ

Patrono: José Carlos Barbosa Moreira. ISSN 1982-7636. pp. 240-281 http://www.e-publicacoes.uerj.br/index.php/redp/index

O que importa para aplicação dos precedentes é perceber que eles dependem das regras de relevância, que são desenvolvidas jurisprudencialmente, para se comparar o precedente ao caso imediato e decidir se é possível aplicá-lo, na explicação de Rosa (2013, p. 30). Esta conceituação diz respeito aos casos em que o precedente é aplicado ou afastado a critério do juiz, em análise do caso, quando não há uma regulamentação legislativa própria a respeito do assunto. No caso do incidente em análise já foi escolhido o critério na própria disposição que prevê a instauração do incidente: ficam vinculadas ao resultado obtido no julgamento do incidente as ações presentes ou futuras que veiculem a mesma questão de direito.

Doutrina encabeçada por Mancuso (2009, p. 341) revela três funções exercidas pelo magistrado ao julgar um caso: resolver o caso concreto (função dikelógica), aplicar a norma de regência do caso (função nomofilácica), e unificar a interpretação e aplicação do direito (função paradigmática).

A função dikelógica se perfaz ao resolver a desigualdade e dirimir o conflito com justiça. Mas a realização desta tarefa leva invariavelmente a outra: a função nomofilácica. Através dela se garante a uniformidade da jurisprudência, porque se concede à decisão a prerrogativa de orientar os casos seguintes. Segundo Rosa (2009, p. 33) "A função nomofilácica de uma corte não é interpretar o direito objetivo, mas unificar o trabalho de interpretação jurisprudencial que vem sendo feito por todos os órgãos judiciários." O mesmo autor atribui ao precedente a prerrogativa de uniformizar, de servir de parâmetro de interpretação e aplicação do direito, conferindo certeza e previsibilidade:

Trata-se do papel de preservar a uniformidade exegética da ordem normativa, dando aquela interpretação que deve ser tida como a correta e única exegese possível para o caso posto a julgamento. Não se deve admitir uma flexibilização da função nomofilácica, pois é inaceitável que, a despeito da pluralidade de órgãos julgadores, o direito admita várias interpretações possíveis e corretas para um mesmo caso. (grifo nosso)

Já em relação à função paradigmática, o precedente cria nos jurisdicionados uma legítima expectativa futura; essa função é corolário da igualdade, uma vez que os casos decididos em determinado sentido, no passado, devem por igualdade criar uma regra a ser 
Revista Eletrônica de Direito Processual - REDP. Volume 16. Julho a dezembro de 2015

Periódico Semestral da Pós-Graduação Stricto Sensu em Direito Processual da UERJ

Patrono: José Carlos Barbosa Moreira. ISSN 1982-7636. pp. 240-281 http://www.e-publicacoes.uerj.br/index.php/redp/index

aproveitada no futuro. O precedente gera desestímulo à judicialização de pretensões contrárias à corrente dominante ou teses sumuladas, e também antecipa e compacta os procedimentos.

Pelo exposto fica demonstrado que o incidente exponenciou as melhores características do julgamento de uma causa, retirando a maior utilidade possível de um julgamento específico, escolhido, que serve de parâmetro para milhares de outros litígios. Assim, o incidente elege argumentações-modelo, representativas da controvérsia, e elege-a como precedente vinculante, orientando a uniformidade de decisões na melhor medida que se pode imaginar (nos processos presentes e nos futuros que contemplarem a questão de direito, a decisão será a mesma). A expectativa futura não se limita à mera expectativa causada por uma decisão favorável, mas a expectativa futura é revestida de uma confiabilidade muito mais forte por ter passado a questão a julgamento através do IRDR. O aspecto de segurança jurídica propiciado pela decisão é ampliado.

A economia processual também é favorecida em grande escala na medida que o esforço argumentativo das partes será empregado uma única vez; ou seja, o sujeito passivo, se for o mesmo para várias causas repetitivas, por exemplo, terá oportunidade de ver sua situação apreciada na oportunidade do julgamento do incidente, e dali para frente a decisão se repetirá. Da mesma forma, as partes não estarão à mercê do "temperamento" ou inclinação doutrinária do juiz para o qual tenha sido distribuída a causa, pois a causa julgada uma vez com justeza, terá o mesmo efeito positivo para todos, gerando isonomia pela resposta judiciária para o mesmo tema.

\section{O INCIDENTE}

Dado o surgimento dos novos direitos sociais, configurados como direitos coletivos pelo surgimento do Estado democrático de Direito, o Estado se volta à proteção concreta da coletividade e não somente do indivíduo, implantando-se a solidariedade social. Assim, as regras processuais revelaram-se inadequadas, por não conseguir abarcar e atender ao objeto e às finalidades dos direitos difusos, coletivos e individuais homogêneos. Para a implantação de um processo adequado, surgiram diplomas legislativos tais como a Lei 4.717/1965, que trata da Ação Popular, e a lei 7.347/1985, a disciplinar a ação civil pública. Depois vieram a ação de improbidade administrativa e também o mandado de segurança coletivo. 
Revista Eletrônica de Direito Processual - REDP. Volume 16. Julho a dezembro de 2015

Periódico Semestral da Pós-Graduação Stricto Sensu em Direito Processual da UERJ

Patrono: José Carlos Barbosa Moreira. ISSN 1982-7636. pp. 240-281 http://www.e-publicacoes.uerj.br/index.php/redp/index

Mas nada disso foi capaz de conter o movimento de massificação de demandas: tornou-se recorrente uma massa de processos a respeito dos mesmos assuntos, das mesmas teses, contra as mesmas pessoas, que circulam entre os tribunais, esperando que se dê adequado tratamento a elas. Isto porque os interesses massificados deram aso ao surgimento de dois modelos de tutela destes interesses: os coletivos e os individuais (repetitivos). A tratativa destas duas esferas de interesse, por suas particularidades, demanda regramentos distintos, em boa definição de Cunha (2010, p. 144):

Para que a tutela jurisdicional seja efetiva, concretizada pela exigência de um devido processo legal, é preciso que haja adequação. O princípio da adequação é extraído, então, da garantia de inafastabilidade do controle jurisdicional, e, igualmente, da cláusula do devido processo legal. O processo deve adequar-se às situações repetitivas. (...) é preciso que as demandas de massa tenham "soluções de massa", ou seja, recebam uma solução uniforme, garantindo-se, inclusive, o princípio da isonomia. Realmente, decorre do princípio da isonomia a necessidade de se conferir tratamento idêntico a quem se encontra em idêntica situação. Daí resulta ser imperioso envidar ingentes esforços no sentido de eliminar as divergências jurisprudenciais.

É preciso "molecularizar" as demandas "atomizadas", criar mecanismos de agrupamento de causas semelhantes. Para tanto foi preciso conceber um mecanismo que pudesse reunir processos individuais para o julgamento uno da questão comum, que no caso, só poderá ser de direito: o incidente de resolução de demandas repetitivas. Ensina Cunha (2010, p. 151) que são eleitas causas-piloto para que se utilize a solução jurisdicional como referência para a resolução de uma pluralidade de controvérsias referentes a um grupo de sujeitos que ostentam o mesmo interesse. Este novo parâmetro de atuação do Judiciário contribui para a racionalidade da técnica processual através da uniformização da jurisprudência. 
Revista Eletrônica de Direito Processual - REDP. Volume 16. Julho a dezembro de 2015

Periódico Semestral da Pós-Graduação Stricto Sensu em Direito Processual da UERJ

Patrono: José Carlos Barbosa Moreira. ISSN 1982-7636. pp. 240-281 http://www.e-publicacoes.uerj.br/index.php/redp/index

$\mathrm{O}$ incidente de resolução de demandas repetitivas é previsto no projeto de lei do Senado de n. ${ }^{\circ}$ 166/2010, Novo CPC, tendo sido inspirado no musterverfahren ${ }^{4}$ do direito alemão, no qual é permitido que se discutam questões de fato e de direito. Nossa importação se limitou às questões de direito. Não se trata necessariamente do mesmo autor ou do mesmo réu, pois não é elemento que deva prevalecer: citando Rosa (2013, p. 104) "não faz diferença quem é a parte, contanto que o pedido e a causa de pedir sejam iguais, o resultado do julgamento deve ser igual".

A possibilidade de suspensão de todos os processos em que se discute idêntica questão de direito já tem sido aventada há bastante tempo por doutrinadores renomados, como elucida Wambier e Medeiros (2011, p. 189). Segundo seu entendimento, o próprio art. 543-C do CPC 1973 deveria ser interpretado de modo a gerar também o sobrestamento não só dos recursos especiais, mas todos os processos que tenham por objeto aquela controvérsia semelhante, para que houvesse aplicação mais isonômica possível das teses jurídicas firmadas pelos Tribunais Superiores. Fica claro então a que a origem do IRDR de fato foi o art. 543-C, CPC 1973, porque tem o mesmo formato e atinge os mesmos objetivos. A grande inovação certamente foi estender o sobrestamento para as ações coletivas.

\subsection{Da confusão teórica}

Para melhor abordar o tema, é importante analisar as razões de sua criação, segundo a exposição de motivos (2010, p. 21) do projeto do CPC/2015:

(...) criou-se, com inspiração no direito alemão, o já referido incidente de resolução de demandas repetitivas, que consiste na identificação de processos que contenham a mesma questão de direito, que estejam ainda em primeiro grau de jurisdição, para decisão conjunta. (...) é admissível quando identificada, em primeiro grau, controvérsia com potencial de gerar multiplicação expressiva

\footnotetext{
4 “Apesar de o CPC prever a instauração do incidente para a definição de questões unicamente de direito, quanto a estas deve ser amplo o cabimento, compreendendo questões de direito material ou processual (art. 928 do CPC/2015 e Enunciado 88 do FPPC) A identidade apenas fática não autoriza, ao contrário do que ocorre no regime alemão, a instauração do incidente brasileiro" (MENDES; TEMER, 2015, p. 291).
} 
Revista Eletrônica de Direito Processual - REDP. Volume 16. Julho a dezembro de 2015

Periódico Semestral da Pós-Graduação Stricto Sensu em Direito Processual da UERJ

Patrono: José Carlos Barbosa Moreira. ISSN 1982-7636. pp. 240-281 http://www.e-publicacoes.uerj.br/index.php/redp/index

de demandas e o correlato risco de coexistência de decisões conflitantes.

Como se vê, buscou-se justificar o instituto do incidente de resolução de demandas repetitivas como um mecanismo de coletivização. Para tanto, abordou o posicionamento de Mancuso (2009, p. 379), para quem a sociedade atual experimenta o fenômeno de "coletivização dos conflitos", pela percepção de que a perspectiva individual que guia o processo civil clássico é incapaz de resolver "megacontrovérsias":

(...) novos instrumentos capazes de recepcionar esses conflitos assim potencializados, seja em função do número expressivo (ou mesmo indeterminado) dos sujeitos concernentes, seja em função da indivisibilidade do objeto litigioso, que o torna insuscetível de participação e fruição por um titular exclusivo.

Contudo, no caso do incidente não há o sobrestamento dos processos a fim de que se possa coletivizar a demanda. A demanda coletiva protegeria titulares indeterminados, mas isto não ocorre na aplicação do incidente; também não se trata aqui de união ou reunião de processos pela indivisibilidade do objeto litigioso. Os dizeres de Mancuso só embasam institutos voltados à proteção de direitos coletivos, não podendo então dar base ao incidente.

A exposição de motivos deixa clara a fonte dos problemas que se experimenta com a aplicabilidade e conceituação do instituto. O termo "incidente de coletivização", que foi inicialmente utilizado, é inadequado porque soa como ação coletiva, quando na verdade o que se tem é direitos coletivamente tratados. Os direitos tratados não são coletivos. A ideia de que se trata de coletivização não faz jus ao resultado, nem às funções a que se visa com a aplicação do incidente.

Importante observação de Rosa (2013, p. 112), ao afirmar que não se reúne as demandas individuais em nada, apenas se julga as questões comuns aos processos individuais: "o incidente, na verdade, é de molecularização de demandas, ele força a uma reunião ou agrupamento para julgamento conjunto das questões comuns, sem contudo coletivizar nada." É esta noção que guia este trabalho. 
Revista Eletrônica de Direito Processual - REDP. Volume 16. Julho a dezembro de 2015

Periódico Semestral da Pós-Graduação Stricto Sensu em Direito Processual da UERJ

Patrono: José Carlos Barbosa Moreira. ISSN 1982-7636. pp. 240-281 http://www.e-publicacoes.uerj.br/index.php/redp/index

\subsection{Conceito de demandas repetitivas}

A redação do dispositivo revela a necessidade de delinear o conceito trazido no $\mathrm{CPC} / 2015$ :

Art. 976. É cabível a instauração do incidente de resolução de demandas repetitivas quando houver, simultaneamente:

I - efetiva repetição de processos (...)

A doutrina nacional, destacando-se Bastos (2010, p. 95) define pelo quantitativo: "Demandas repetitivas caracterizam-se por veicularem, em larga escala, situações jurídicas homogêneas que são apresentadas em larga escala ao judiciário" (grifo nosso).

Invariavelmente o conceito jurídico indeterminado deixa dúvidas e conta com a razoabilidade do operador do direito. O que seria larga escala? Centenas em certa região? A importância ou alcance do dano? Pouco foi definido. O tema é novo e acredita-se que o desenvolvimento doutrinário acerca do incidente, aliado à prática, trará as respostas a estas perguntas. Será preciso estudar a homogeneidade, como diz Cunha (2011, p. 259):

Várias demandas individuais podem caracterizar-se como causas repetitivas, assim como várias demandas coletivas podem ser causas repetitivas. O que importa não é o objeto litigioso, mas a homogeneidade, ou seja, a existência de situações jurídicas homogêneas. A litigiosidade de massa é o que identifica as demandas repetitivas, independentemente de o direito ser individual ou coletivo.

Há que definir, então, o que seriam as situações jurídicas homogêneas. Ao contrário do que se costuma afirmar, pontua Bastos (2010, p. 97) que demandas repetitivas não se resumem aos direitos individuais homogêneos. "Cuida-se de demandas-tipo, decorrentes de uma relação-modelo, que ensejam soluções-padrão". Neste caso, os elementos objetivos, quais sejam, a causa de pedir e pedido, assemelham-se mas não chegam a se identificar, até 
Revista Eletrônica de Direito Processual - REDP. Volume 16. Julho a dezembro de 2015

Periódico Semestral da Pós-Graduação Stricto Sensu em Direito Processual da UERJ

Patrono: José Carlos Barbosa Moreira. ISSN 1982-7636. pp. 240-281 http://www.e-publicacoes.uerj.br/index.php/redp/index

porque, se fossem idênticos, haveria conexão. Não há comunhão de direitos, nem de obrigações; também não há um só evento danoso.

É o que ocorre quando vários correntistas defendem em juízo que certa tarifa bancária é indevida, quando certos segurados buscam a correção monetária de um benefício previdenciário. Não é mesmo o pedido (não pedem todos a devolução em dobro do valor ou o reajuste do benefício em certa porcentagem) nem a mesma causa de pedir (não é um só contrato nem uma só relação entre um segurado e a previdência): os processos são ligados por mera afinidade. A identidade ocorre ao se determinar uma relação-modelo, e este delineamento com a causa de pedir e pedido padronizados importa para o julgamento e sobrestamento dos recursos repetitivos, importando, então, para aplicação do IRDR. Assim, ocorre identidade em tese, e não em concreto, da causa de pedir e pedido.

Além da similitude da causa de pedir e pedido, as demandas repetitivas são marcadas pela massificação, repetição em grande quantidade, que é o ocasiona a morosidade e divergência de resultados.

Como dito, comumente são confundidos os direitos individuais homogêneos e os direitos repetitivos. Esta equiparação não merece prosperar. Os direitos repetidos formam uma outra categoria, e pode ou não ser formada por direitos tipicamente coletivos. Sempre que um direito coletivo lato sensu perpassar questão de direito, teremos um direito repetitivo. Alguns direitos coletivos poderão ser demandas repetitivas, e estarão veiculadas em demanda individual ou coletiva; de qualquer sorte, se aplica o incidente de resolução. Mas nem toda demanda repetitiva envolve direitos coletivos: às vezes, só direitos individuais propriamente ditos, que pela quantidade e impacto social, precisem ser suspensos e julgados uniformemente.

Ocorre, assim, que as situações jurídicas homogêneas não se restringem aos interesses individuais homogêneos, mas também os direitos individuais homogêneos não serão sempre situações jurídicas homogêneas.

Veja que há situações jurídicas assemelhadas e repetidas, sendo então, homogêneas, mas que não chegam a ser direitos individuais homogêneos; isto porque é preciso homogeneidade e origem comum para que se configurem os direitos individuais homogêneos. Atentemos para Rosa (2013, p. 108): "Não é preciso origem comum para se reputar repetido um direito. Pode haver homogeneidade, e certamente alguma há de estar 
Revista Eletrônica de Direito Processual - REDP. Volume 16. Julho a dezembro de 2015

Periódico Semestral da Pós-Graduação Stricto Sensu em Direito Processual da UERJ

Patrono: José Carlos Barbosa Moreira. ISSN 1982-7636. pp. 240-281 http://www.e-publicacoes.uerj.br/index.php/redp/index

presente, mas é uma homogeneidade bem mais superficial que a necessária para os direitos individuais homogêneos."

E há direitos individuais homogêneos que não ensejam repetição de demandas, pois apesar do dano ser extenso, não é útil, haja vista a relação custo e tempo que envolve a ação processual, a cada titular individual pleiteá-lo, de modo que somente um ou alguns poucos legitimados extraordinários ajuízam a demanda. É o exemplo em que, a despeito da informação contida na embalagem, produto tem o peso efetivo de $10 \mathrm{~g}$ a menos que o informado; provavelmente os titulares individuais não ajuizarão ação para defender seu direito, e assim não teremos repetição da demanda.

Esclarece Rosa (2013, p. 107) que "direitos repetidos podem ser relacionados a fatos completamente distintos, e ainda assim serão repetidos se veicularem as mesmas questões de direito"; e os direitos individuais homogêneos se relacionam com o mesmo fato, para que haja identidade. Os direitos individuais homogêneos também podem ser definidos como pertencentes a um grupo a priori; enquanto para os direitos repetidos é impossível estabelecer a priori um conjunto de titulares, porque sua identificação só decorre da situação concreta de o direito de que são titulares ser repetitivo.

As situações jurídicas homogêneas são as demandas repetitivas que podem ser objeto do incidente.

\subsection{Grinover: uma visão apurada sobre o direito coletivo}

$\mathrm{O}$ art. 139, X, CPC nos auxilia a melhor compreender a extensão e tratativa dispensada pelo CPC 2015 aos direitos individuais homogêneos:

Art. 139. O juiz dirigirá o processo conforme as disposições deste Código, incumbindo-lhe:

$X$ - quando se deparar com diversas demandas individuais repetitivas, oficiar o Ministério Público, a Defensoria Pública e, na medida do possível, outros legitimados a que se referem o art. $5^{\circ}$ da Lei $\mathrm{n}^{0} 7.347$, de 24 de julho de 1985 , e o art. 82 da Lei $\mathrm{n}^{\circ} 8.078$, de 11 de setembro de 1990, para, se for o caso, promover a propositura da ação coletiva respectiva. 
Revista Eletrônica de Direito Processual - REDP. Volume 16. Julho a dezembro de 2015

Periódico Semestral da Pós-Graduação Stricto Sensu em Direito Processual da UERJ

Patrono: José Carlos Barbosa Moreira. ISSN 1982-7636. pp. 240-281 http://www.e-publicacoes.uerj.br/index.php/redp/index

Grinover (2011, p. 3) lembra que a ação coletiva em defesa dos direitos individuais homogêneos chegou a ser denominada "ação de classe brasileira", por encontrar seu precedente nas class actions for damages do sistema norte-americano. Assim, passa à análise dos requisitos aplicáveis ao instituto americano.

A origem comum que marca os direitos individuais homogêneos pode ser de fato ou de direito. A origem comum é a causa, que pode ser próxima ou remota. Por exemplo, será próxima ou imediata a causa de queda de um avião que ocasionou a morte de várias pessoas; será remota quando, analisando um dano à saúde, imputado a um produto potencialmente nocivo, que teria como causa próxima as condições particulares de saúde do sujeito, ou o uso inadequado do produto. A autora, seguindo Kazuo Watanabe, acredita que há uma escala: "quanto mais remota a causa, menos homogêneos serão os direitos" (GRINOVER, 2011, p. 4).

Então a origem comum, se for muito remota, pode descaracterizar o direito como individual homogêneo. Se, por exemplo, um sujeito A sofreu dano ocasionado exclusivamente pelo consumo do produto, é diferente daquele cujas condições pessoais de saúde teriam lhe causado um dano físico que fosse independente da utilização do produto. Não haverá homogeneidade entre situações de fato ou de direito se as particularidades do titular atuarem no caso de forma muito diferente. Para ela, se não houver esta prevalência dos aspectos coletivos, os direitos serão na realidade heterogêneos, mesmo que sua origem seja comum, por ser a causa remota. Haveria impossibilidade jurídica do pedido de tutela coletiva. Para Grinover, (2011, p. 4), só a prevalência das questões comuns demonstraria a homogeneidade do direito:

a prevalência das questões comuns sobre as individuais, que é condição de admissibilidade no sistema das class actions for damages norte-americanas, também o é no ordenamento brasileiro, que só possibilita a tutela coletiva dos direitos individuais quando estes forem homogêneos.

O segundo requisito aplicável as class actions é o de superioridade das questões comuns face às individuais. A superioridade deve ser vista sob o prisma de justiça e eficácia 
Revista Eletrônica de Direito Processual - REDP. Volume 16. Julho a dezembro de 2015

Periódico Semestral da Pós-Graduação Stricto Sensu em Direito Processual da UERJ

Patrono: José Carlos Barbosa Moreira. ISSN 1982-7636. pp. 240-281 http://www.e-publicacoes.uerj.br/index.php/redp/index

da decisão, e aplicada ao direito brasileiro, divide-se em superioridade do interesse de agir e

o da efetividade do processo. $\mathrm{Na}$ verdade, melhor que falar em superioridade, em direito brasileiro deveríamos falar em necessidade de que a eficácia da tutela seja coletiva. Se o provimento jurisdicional resultante da ação coletiva não é tão eficaz quanto nas ações individuais, a ação coletiva não é útil à tutela dos interesses, e assim, não é adequada à sua proteção.

Há que reparar no caso concreto a necessidade de prova e a utilidade da tutela coletiva:

(...) a prova do nexo causal pode ser simples: na queda de um avião, num acidente provocado pelo desmoronamento de um edifício, na explosão de uma fábrica, na lesão aos consumidores por diferença de peso no produto vendido, a utilidade da sentença coletiva será inquestionável. Mas em outros casos, tudo deverá ainda ser provado no processo de liquidação, tornando uma falácia a sentença condenatória genérica.(GRINOVER, 2011, p. 7).

Esta ideia reforça uma noção de que não basta homogeneidade para instaurar a ação coletiva, mas necessidade e adequação. Pode-se postular que, com a criação do incidente, mais que nunca, devem ser ajuizadas as ações coletivas para tutela de direitos individuais homogêneos somente quando necessário e adequado à sua proteção. Isto porque os direitos individuais homogêneos podem ser buscados por ação individual ou ação coletiva, mas ação coletiva só quando as peculiaridades do direito assim o exigirem - quando for necessário ao acesso à justiça, quando os sujeitos não tiverem interesse individual real em propor a ação individual e o dano coletivo esteja assim descoberto. Deve-se perguntar: a tutela coletiva é a única possível no caso concreto? Perceba-se que em sede de direitos difusos e direitos coletivos stricto sensu, não teremos ajuizamento de várias demandas repetitivas, porque são direitos insuscetíveis de apropriação individual, e ajuizáveis somente por legitimados extraordinários, pelo sistema de substituição processual, segundo Zavascki (2005, p. 32). Em relação aos direitos individuais homogêneos, estes fazem parte do patrimônio do titular e pode por ele próprio ser protegido mediante demanda individual. 
Revista Eletrônica de Direito Processual - REDP. Volume 16. Julho a dezembro de 2015

Periódico Semestral da Pós-Graduação Stricto Sensu em Direito Processual da UERJ

Patrono: José Carlos Barbosa Moreira. ISSN 1982-7636. pp. 240-281 http://www.e-publicacoes.uerj.br/index.php/redp/index

$\mathrm{Na}$ verdade, aplicam-se ao art. 139, X, CPC a comunicação aos legitimados extraordinários sobre as demandas repetitivas quando não forem muitas as demandas, e representarem um verdadeiro direito individual homogêneo, de tutela acessível a poucos titulares, pelo custo da demanda ou mesmo pelo dano em si, que assim enseja que um legitimado extraordinário atue para protegê-lo. Ou seja, que necessite de tutela coletiva.

Grinover traz parâmetros eficientes para a definir o objeto do incidente, inspirados nas class actions, que acredita implicitamente instituídos no ordenamento jurídico brasileiro, de tal sorte que há direitos individuais homogêneos que são, realmente, direitos repetitivos que podem ser demandados por ação individual ou coletiva. Contudo, há direitos individuais homogêneos que têm um sentido tão forte de transindividualidade que dependem de ação coletiva para se realizar, pois os titulares individuais não têm meios para provar, ou a relação custo-benefício da defesa do direito lhes impede de pleiteá-lo. Há direitos então que, formalmente, podem ser protegidos pelos dois tipos de tutela, mas que a situação concreta aponta que é necessário processamento coletivo para que se realize o direito e impeça o dano, conclamando a ação coletiva por uma questão de concretização do princípio de acesso à justiça como processo justo.

Dadas as dificuldades desde sempre experimentadas pela tutela coletiva, em já havendo muitas demandas repetitivas ajuizadas, o pleito através de demanda coletiva será ineficaz: teremos mais uma ação, agora coletiva, para abarrotar o Judiciário, e ao lado dela um sem número de ações individuais, e no futuro poderão ainda ser ajuizadas outras individuais, pois a coletiva não exclui as outras. Se entendermos que neste caso a ação coletiva será apenas a soma dos pedidos individuais, a reunião das ações, não gera nenhuma vantagem, sendo muito mais vantajoso aplicar o IRDR.

Já para a ação individual que encerre um direito individual homogêneo cuja tutela coletiva represente mais que uma reunião de ações, atuando como um verdadeiro novo pedido transindividual ${ }^{5}$, deve ser utilizada a comunicação prevista no art. $139, \mathrm{X}, \mathrm{CPC}$ pelos

\footnotetext{
5 "Trata-se de um grupo de vítimas. A relação que se estabelece entre as pessoas envolvidas surge exatamente em decorrência da lesão, que tem origem comum: essa comunhão na ancestralidade da lesão torna homogêneos os direitos individuais. Criado o grupo, permite-se a tutela coletiva, cujo objeto, como em qualquer ação coletiva, é indivisível (fixação da tese jurídica geral); a diferença, no caso, reside na possibilidade de, em liquidação e execução da sentença coletiva, o quinhão devido a cada vítima pode ser individualizado." (DIDIER JR; ZANETI JR, 2013, p. 84).

O direito em si é divisível, apesar de considerar-se uno o objeto após formada a ação coletiva de direitos individuais homogêneos. Alguns autores, como Teori Albino Zavascki, apontam que esta ação consiste na verdade em direitos coletivamente tratados; outros, que "uma ação coletiva para a defesa de direitos individuais homogêneos não significa a simples soma das ações individuais. Às avessas, caracteriza-se a ação coletiva por
} 
Revista Eletrônica de Direito Processual - REDP. Volume 16. Julho a dezembro de 2015

Periódico Semestral da Pós-Graduação Stricto Sensu em Direito Processual da UERJ

Patrono: José Carlos Barbosa Moreira. ISSN 1982-7636. pp. 240-281 http://www.e-publicacoes.uerj.br/index.php/redp/index

legitimados com sabedoria, procedendo então ao ajuizamento da ação coletiva, por ser verdadeira medida de acesso à justiça.

\subsection{Primeiro requisito de aplicação do IRDR: repetição da questão de direito}

Foram previstos requisitos objetivos para delinear os processos sujeitos à aplicação do incidente, pelo art. 976, CPC/2015:

Art. 976. É cabível a instauração do incidente de resolução de demandas repetitivas quando houver, simultaneamente:

I - efetiva repetição de processos que contenham controvérsia sobre a mesma questão unicamente de direito;

Questão é qualquer ponto controverso, de fato ou de direito, que demande pronunciamento judicial, como explica Didier (2010, p. 305). Não ficou definido claramente no texto legal se a questão possa ser principal ou incidental. Ao nos pautar por uma interpretação pelo princípio da razoabilidade, entendemos que o sobrestamento do feito só se justifica se for a questão principal, pois o processo ficará suspenso, sem tramitação. Se nos basearmos no critério de distinção baseado no objeto da questão, concluiremos que é fática a questão que tem por objeto um fato, e de direito se relaciona-se à própria norma, a fato ou efeito jurídico.

Mas este critério é pouco elucidativo e prático, já que dentro do suporte fático concreto pode haver um fato jurídico (fato com implicações jurídicas após a incidência normativa). Por exemplo, os fatos aptos a ensejar a rescisão da sentença trazem questões jurídicas, tais como a prevaricação, concussão, e nem por isso se configuram de fato como questões de direito.

A distinção baseada em critério funcional é mais eficaz: questão de fato é "toda aquela relacionada aos pressupostos fáticos da incidência” (DIDIER, 2010, p. 306), sempre que esteja relacionada ao suporte fático concreto; não a descaracterizará se o critério do objeto a classificar diferentemente. Será questão de direito sempre que se relacionar com a tarefa de subsunção do fato à norma.

interesses individuais homogêneos exatamente porque a pretensão do legitimado concentra-se no acolhimento de uma tese jurídica geral, referente a determinados fatos, que pode aproveitar a muitas pessoas. O que é completamente diferente de apresentarem-se inúmeras pretensões singularizadas, especificamente verificadas em relação a cada um dos respectivos titulares do direito." (ARAUJO FILHO, 2000, p. 114, apud DIDIER JR; ZANETI JR, 2013, p. 82). 
Revista Eletrônica de Direito Processual - REDP. Volume 16. Julho a dezembro de 2015

Periódico Semestral da Pós-Graduação Stricto Sensu em Direito Processual da UERJ

Patrono: José Carlos Barbosa Moreira. ISSN 1982-7636. pp. 240-281 http://www.e-publicacoes.uerj.br/index.php/redp/index

As questões de direito poderão sempre ser apreciadas de ofício pelo juiz; por outro lado, algumas questões de fato dependem de provocação da parte interessada, outras não. Como as questões de direito não dependem de provocação, podem sempre ser analisadas, facilita a aplicação do art. 333, CPC, já que não há que ponderar caso a caso se a questão foi suscitada: basta que ela esteja presente no processo para que haja suspensão e aplicação do incidente.

Aqui será empregada a técnica de isolamento da questão jurídica central comum às ações repetitivas, chamado de fenômeno da cisão da cognição judicial, assim como o empregado no julgamento por amostragem dos recursos excepcionais. Extrai-se a questão de direito dos fatos, que não são relevantes para a definição da tese. Ainda que haja fatos subjacentes às questões que se deve resolver, estes são inteiramente absorvidos pelas expressões levadas na questão de direito, segundo Rodrigues (et al, 2013, p. 188). Por exemplo, cabe para as mães adotivas certo benefício previdenciário? Sua idade, prova ou data da adoção, nada disto importa à resolução da questão de direito que se extrai e que é comum aos processos repetidos.

\subsection{Segundo requisito: risco de ofensa à isonomia e à segurança jurídica}

O incidente ora estudado inaugura um novo sistema de resolução coletiva de litígios, que se processa através de escolha de "processos-piloto". Selecionam-se alguns processos representativos de toda a controvérsia, de preferência aqueles que contenham maior variabilidade de argumentos e cujas decisões contemplem o maior número de fundamentos, enquanto os outros processos repetitivos serão suspensos, aguardando a decisão da tese comum.

Os requisitos são cumulativos, e o segundo é de conteúdo mais aberto, mas sua análise não precisa ser por isso truncada (CPC, BRASIL, 2015):

Art. 976. É cabível a instauração do incidente de resolução de demandas repetitivas quando houver, simultaneamente:

I - efetiva repetição de processos que contenham controvérsia sobre a mesma questão unicamente de direito;

II - risco de ofensa à isonomia e à segurança jurídica. 
Revista Eletrônica de Direito Processual - REDP. Volume 16. Julho a dezembro de 2015

Periódico Semestral da Pós-Graduação Stricto Sensu em Direito Processual da UERJ

Patrono: José Carlos Barbosa Moreira. ISSN 1982-7636. pp. 240-281 http://www.e-publicacoes.uerj.br/index.php/redp/index

Este requisito revela uma aproximação dos mecanismos de uniformização de jurisprudência preventiva, pois independe de prévia divergência jurisprudencial na interpretação de certa tese jurídica.

Como aponta Bueno (2011, p. 411), o art. 555, §1º, CPC/1973 já destacava a relevante questão de direito para julgamento, e se refere a teses jurídicas que tenham aptidão de gerar recursos múltiplos ou repetitivos - e por isso justifica que o Tribunal se manifeste desde o início sobre o assunto, para evitar um conflito de entendimentos, que "em última análise, atrita com o 'princípio da isonomia' (...) e, mais amplamente, com o próprio 'princípio da segurança jurídica".

Art. 555, $\S 1^{\circ}$ o Ocorrendo relevante questão de direito, que faça conveniente prevenir ou compor divergência entre câmaras ou turmas do tribunal, poderá o relator propor seja o recurso julgado pelo órgão colegiado que o regimento indicar; reconhecendo o interesse público na assunção de competência, esse órgão colegiado julgará o recurso.

Da mesma forma, o incidente se propõe à uniformização preventiva, evitando a interposição de recursos posteriormente com o objetivo de sanar a divergência. Entende-se que não abrir espaço para múltiplas decisões é verdadeira medida de justiça, de tal sorte que a iniciativa preventiva do IRDR é louvável.

No caso do art. 555, $\S 1^{\circ}, \mathrm{CPC} / 1973^{6}$ postulava-se que (BUENO, 2011, p. 412) “o magistrado, antevendo que a questão pode multiplicar-se (...) poderia requerer que o órgão colegiado indicado no Regimento interno do STJ ou STF se manifestasse desde logo sobre a interpretação que deveria ser aplicada à hipótese.” Contudo, diferentemente, no IRDR as

\footnotetext{
${ }^{6}$ Seu equivalente no CPC 2015 seria o art. 947, chamado de "incidente de assunção de competência", pelo que o julgamento é entregue ao colegiado, quando houver questão de direito de grande repercussão social, mas sem repetição em demandas. Também privilegia o caráter preventivo da uniformização de jurisprudência.

"Art. 947. É admissível a assunção de competência quando o julgamento de recurso, de remessa necessária ou de processo de competência originária envolver relevante questão de direito, com grande repercussão social, sem repetição em múltiplos processos.

$\S 1^{\circ}$ Ocorrendo a hipótese de assunção de competência, o relator proporá, de ofício ou a requerimento da parte, do Ministério Público ou da Defensoria Pública, que seja o recurso, a remessa necessária ou o processo de competência originária julgado pelo órgão colegiado que o regimento indicar."
} 
Revista Eletrônica de Direito Processual - REDP. Volume 16. Julho a dezembro de 2015

Periódico Semestral da Pós-Graduação Stricto Sensu em Direito Processual da UERJ

Patrono: José Carlos Barbosa Moreira. ISSN 1982-7636. pp. 240-281 http://www.e-publicacoes.uerj.br/index.php/redp/index

demandas já se multiplicaram, de modo que haverá o risco de ofensa à isonomia e segurança jurídica, pois o risco é inerente à repetição de demandas.

Surge portanto um direito (corolário do art. $5^{\circ}$, caput e XXXV, da Constituição Federal de 1988) a que as demandas repetidas sejam tratadas coletivamente, não do ponto de vista da tese de fundo discutida (...) mas do julgamento equivalente para situações iguais (...) poder-se-ia fazer referência a um direito meta-processual a que as demandas repetidas sejam tratadas coletivamente. (ROSA, 2013, p. 106).

Configura-se em verdadeiro direito, corolário do princípio da isonomia, a que a resposta jurisdicional seja uniforme às situações homogêneas postas para julgamento.

\subsection{Procedimento}

O incidente de resolução de demandas repetitivas permite que se julgue conjuntamente as questões de direito que são iguais para diversos processos individuais. Elege-se a questão repetida, é proposto o incidente e o Tribunal competente julga somente esta questão, impondo o resultado do julgamento às demais demandas. As ações prosseguem para ser julgadas plenamente individualmente, mas respeitando o resultado do incidente, por previsão do art. 978, CPC/2015.

Pode o incidente ser suscitado pelo magistrado ${ }^{7}$, ex officio, ou a requerimento das partes, Ministério Público ou Defensoria Pública. Será dirigido ofício ou petição ao Presidente do respectivo Tribunal por meio do qual for suscitado o incidente, e será instruído por documentos que demonstrem a necessidade de instauração do incidente. As alegações devem fundar-se em prova documental, não sendo cabível outro tipo de prova para a demonstração da necessidade de ser admitido o incidente.

Será então distribuído a um relator do Plenário do Tribunal ou Órgão Especial competente, que poderá requisitar informações ao juízo de primeiro grau, que terá quinze

\footnotetext{
${ }^{7}$ Pode ser suscitado pelo juiz de uma das causas repetitivas ou pelo relator de um recurso interposto numa das causas repetitivas.
} 
Revista Eletrônica de Direito Processual - REDP. Volume 16. Julho a dezembro de 2015

Periódico Semestral da Pós-Graduação Stricto Sensu em Direito Processual da UERJ

Patrono: José Carlos Barbosa Moreira. ISSN 1982-7636. pp. 240-281 http://www.e-publicacoes.uerj.br/index.php/redp/index

dias para prestá-las. Findo o prazo, é fixada data para examinar a admissibilidade do incidente. O Tribunal verificará se os requisitos para instauração estão preenchidos e se há efetiva conveniência na fixação da tese jurídica com a adoção de decisão paradigmática, explicação de Cunha (2010, p. 272).

Se o incidente for rejeitado, será retomada a ação originária; aceito, serão suspensas todas as ações pendentes em primeiro e em segundo grau que tragam a mesma questão. Neste procedimento nada será julgado, apenas é afirmada a tese jurídica. Tem por objetivo principal a fixação da correta tese jurídica a ser aplicada naquelas hipóteses.

Serão ouvidos todos os interessados e entidades que tenham interesse na controvérsia, em prazo comum de 15 dias. Após, será ouvido o Ministério Público para manifestação.

Concluídas as diligências, o relator pedirá dia para julgamento do incidente. Será então remetido para julgamento do Plenário ou Órgão Especial, ocasião em que poderão até se manifestar autor e réu do processo originário, e Ministério Público, cada um tendo direito a trinta minutos. Depois se manifestarão os eventuais interessados, num prazo comum de trinta minutos, desde que tenha havido inscrição com quarenta e oito horas de antecedência.

A suspensão vige por certo prazo: se não julgado o incidente em um ano, encerra-se a suspensão dos processos, salvo se houver decisão fundamentada do relator.

Julgada a questão, será lavrado acórdão, que será imposto a todos os juízes ou órgãos fracionários no âmbito daquela competência territorial. O incidente será submetido a ampla divulgação, por meio de cadastro mantido pelo $\mathrm{CNJ}$, alimentado por dados fornecidos pelos tribunais, como o modelo alemão que inspirou sua criação. A divulgação garante a publicidade necessária à efetiva uniformização e possibilita maior controle de sua aplicação.

Diferente do julgamento por amostragem dos recursos excepcionais, em sede de IRDR a decisão será dada pelos órgãos de segunda instância, quais sejam, os Tribunais Regionais Federais e os Tribunais de Justiça dos Estados, de tal sorte que a decisão valerá para todo o território onde o Tribunal prolator exerça sua competência.

Após o julgamento, pode ser interposto recurso especial ou extraordinário, que terá neste caso efeito suspensivo. Ou seja, da decisão do incidente é cabível recurso para o Tribunal Superior, que neste caso emitirá precedente definitivo sobre o tema. Não será feito juízo de admissibilidade na origem, remetendo-se direto para o tribunal competente julgar o 
Revista Eletrônica de Direito Processual - REDP. Volume 16. Julho a dezembro de 2015

Periódico Semestral da Pós-Graduação Stricto Sensu em Direito Processual da UERJ

Patrono: José Carlos Barbosa Moreira. ISSN 1982-7636. pp. 240-281 http://www.e-publicacoes.uerj.br/index.php/redp/index

recurso interposto. Então o juízo de admissibilidade do recurso especial ou extraordinário no incidente é exercido exclusivamente pelo tribunal superior.

Se for desrespeitada a tese da decisão paradigmática, cabe Reclamação para o tribunal competente.

(...) a extensão da eficácia da decisão acerca da tese jurídica limitase à área de competência territorial do tribunal, salvo decisão em contrário do STF ou dos Tribunais Superiores, pleiteada pelas partes, interessados, MP ou Defensoria Pública. (BRASIL, 2010, p. 12).

Caso se faça necessário, para preservar a segurança jurídica, as partes, interessados, Defensoria Pública ou Ministério Público poderão requerer a determinação da suspensão dos processos em todo o país que abordem a mesma questão objeto do incidente. Se a matéria for constitucional e provável a interposição de recurso extraordinário, o pedido será dirigido ao STF; se for matéria infraconstitucional, ao STJ será requerida a suspensão dos processos em todo o território nacional.

A aplicação da tese jurídica terá eficácia então, inicialmente, no âmbito territorial do tribunal, salvo se a questão tiver alcance nacional e for interposto pedido ao STJ ou STF através de recurso extraordinário ou especial. ${ }^{8}$

Art. 982, § $3^{\mathrm{o}}$ Visando à garantia da segurança jurídica, qualquer legitimado mencionado no art. 977, incisos II e III, poderá requerer, ao tribunal competente para conhecer do recurso extraordinário ou especial, a suspensão de todos os processos individuais ou coletivos em curso no território nacional que versem sobre a questão objeto do incidente já instaurado.

\footnotetext{
${ }^{8}$ Melhor explicando sobre a aplicação: "Após o julgamento e definição da tese jurídica no procedimento incidental, haverá a aplicação do entendimento jurídico a todos os processos, individuais ou coletivos, que versem sobre idêntica questão de direito e que tramitem na área de jurisdição do respectivo tribunal, inclusive àqueles que tramitem nos juizados especiais do respectivo estado ou região, para possibilitar o julgamento da causa propriamente dita. Do mesmo modo, será aplicada aos casos futuros que versem idêntica questão de direito e que venham a tramitar na esfera territorial do tribunal. Não haverá, naturalmente, limitação territorial, se houver recurso para o STF ou para o STJ, tendo em vista o caráter nacional desses tribunais." (MENDES; TEMER, 2015, p. 301)
} 
Revista Eletrônica de Direito Processual - REDP. Volume 16. Julho a dezembro de 2015

Periódico Semestral da Pós-Graduação Stricto Sensu em Direito Processual da UERJ

Patrono: José Carlos Barbosa Moreira. ISSN 1982-7636. pp. 240-281 http://www.e-publicacoes.uerj.br/index.php/redp/index

Pode haver inversão de instâncias, se for prevista em lei federal, quando a questão comum é julgada primeiro pelo tribunal e só depois imposta ao primeiro grau de jurisdição - primeiro é afirmada a posição do órgão hierarquicamente superior, e depois se impõe ao julgador o resultado, evitando revisão pelo duplo grau de jurisdição, como ensina Rosa (2013, p. 118).

Alguns autores já defendiam a ideia veiculada pelo instituto do IRDR mesmo em ocasião de redações anteriores à definitiva, em que faltava instrumento uniformizador da tese, como Castelo Branco Neto (2015, p. 14), refletindo que a tese jurídica merece ser idêntica em todo o país, pois a tratativa dada pelos tribunais deve ser igualitária aos jurisdicionados.

O comprometimento dos realizadores do processo com o julgamento uniforme para questões de mesma tese jurídica nos faz sustentar que deveriam ser suspensas todas as ações, pelo STJ e/ou STF, após lhes ser dado o conhecimento pelo respectivo tribunal onde o incidente já estivesse sido admitido, pois estamos a tratar de um processo objetivo, onde não há partes, e sim discussão da tese que prevalecerá aos casos iguais. (grifo nosso).

O CPC/2015, como fica claro pelas disposições normativas supraelencadas, adotou este posicionamento, privilegiando a isonomia entre os jurisdicionados e possibilitando igualar a tese por todo o país.

\section{APLICAÇÃO DO INCIDENTE}

O incidente será aplicado a todos os processes individuais ou coletivos, que versem sobre a questão de direito, no campo de jurisdição do respectivo tribunal. Este posicionamento inaugura uma nova possibilidade para a relação travada entre demandas individuais e coletivas que versem sobre o mesmo direito: a possibilidade de, instaurado o incidente, uma ação coletiva ser eleita como causa piloto e suspenderem-se todas as ações individuais. E ainda vai além: aplica o resultado obtido, em sede de ação coletiva, para a 
Revista Eletrônica de Direito Processual - REDP. Volume 16. Julho a dezembro de 2015

Periódico Semestral da Pós-Graduação Stricto Sensu em Direito Processual da UERJ

Patrono: José Carlos Barbosa Moreira. ISSN 1982-7636. pp. 240-281 http://www.e-publicacoes.uerj.br/index.php/redp/index

demanda individual, apesar da ação coletiva não induzir litispendência e não submeter a coisa julgada obtida ao final de seu julgamento às ações individuais.

O Superior Tribunal de Justiça, no julgamento do REsp 1110549/RS, decide pela aplicação do art. 543-C, CPC 1973, já estudado, no âmbito das ações coletivas:

RECURSO REPETITIVO. PROCESSUAL CIVIL. RECURSO ESPECIAL. AÇÃO COLETIVA. MACRO-LIDE. CORREÇÃO DE SALDOS DE CADERNETAS DE POUPANÇA. SUSTAÇÃO DE ANDAMENTO DE AÇÕES INDIVIDUAIS. POSSIBILIDADE. 1.- Ajuizada ação coletiva atinente a macro-lide geradora de processos multitudinários, suspendem-se as ações individuais, no aguardo do julgamento da ação coletiva. 2.Entendimento que não nega vigência aos aos arts. 51, IV e $\S 1^{\circ}, 103$ e 104 do Código de Defesa do Consumidor; 122 e 166 do Código Civil; e $2^{\mathrm{o}}$ e $6^{\mathrm{o}}$ do Código de Processo Civil, com os quais se harmoniza, atualizando-lhes a interpretação extraída da potencialidade desses dispositivos legais ante a diretriz legal resultante do disposto no art. 543-C do Código de Processo Civil, com a redação dada pela Lei dos Recursos Repetitivos (Lei n. 11.672, de 8.5.2008). 3.- Recurso Especial improvido.

(STJ, Relator: Ministro SIDNEI BENETI, Data de Julgamento: 28/10/2009, S2 - SEGUNDA SEÇÃO)

Apesar de o princípio do devido processo legal e o respeito ao processo justo pugnarem pela divisão do âmbito da ação coletiva e ação individual, considerando inclusive os debates a respeito de o pedido coletivo conter o individual ou não, parece que a intenção do legislador foi de realmente possibilitar o decidido pelo STJ.

Interessante notar como os problemas contemporâneos experimentados pelos operadores do direito conduzem à noção de se estender a aplicação de uma única tese jurídica na maior medida possível, para processos pendentes no momento de instauração de incidentes e também futuros, para processos individuais e coletivos simultaneamente. Este 
Revista Eletrônica de Direito Processual - REDP. Volume 16. Julho a dezembro de 2015

Periódico Semestral da Pós-Graduação Stricto Sensu em Direito Processual da UERJ

Patrono: José Carlos Barbosa Moreira. ISSN 1982-7636. pp. 240-281 http://www.e-publicacoes.uerj.br/index.php/redp/index

quadro revela que a divergência jurisprudencial tem se mostrado intolerável ao jurisdicionado e aumentado a litigiosidade, já que instiga o sentimento de inconformidade e suscita o ajuizamento de vários recursos visando atacar a multiplicidade de leituras - o que se quer, cada vez mais, é que se possa debruçar sobre a causa e fazer um bom julgamento uma única vez, e reproduzi-lo por medida de isonomia.

O legislador procurou se desvincular dos problemas próprios da tutela coletiva, e, ambicioso, acredita poder confiar numa isonomia "cega": porque não igualdade entre ações coletivas e individuais? Ora, ações individuais e coletivas não devem se misturar, tem suas particularidades e limitações próprias. Não se discute no âmbito do IRDR a representatividade adequada, porque não há representantes de titulares de um direito "comum" - cada um tem seu direito, que será decidido pelo juiz natural, mas a questão de direito é repetida. No caso do incidente ocorre é apenas a eleição de causas-piloto de modo a formar um microssistema da macrocontrovérsia, julgando o que há em comum. Já na ação coletiva, a ação é julgada para todos os titulares, porque o direito em questão é compartilhado pelos sujeitos. A pretensão do legislador em suspender ações individuais e coletivas ao mesmo tempo viola o procedimento próprio delineado para adequado tratamento de cada uma delas e gera consequências inaceitáveis.

Bastos (2010, p. 99), ao desenhar o conceito de situações jurídicas homogêneas, acaba definindo as hipóteses de cabimento do IRDR, revelando que de fato foi este conceito que guiou o legislador para a feitura do instituto, e deixou claro sua aplicação também para ações coletivas de modo a evitar debate doutrinário e impasse jurisprudencial. Defendeu ainda a aplicação do art. 543-C, CPC/1973 a estas situações jurídicas repetitivas - pois assim se prestigiaria a racionalização do julgamento das demandas repetitivas.

Podemos considerar os interesses individuais homogêneos como objeto das demandas repetitivas, sim. (...) enfocando o conjunto de processos repetitivos, cuidar-se-à de uma demanda tipo, em relação

\footnotetext{
${ }^{9}$ Mas nem sempre é assim. Para Rosa, falta um controle de representatividade adequada no IRDR: "não há uma participação efetiva de qualquer outra pessoa que será afetada, apenas a oportunidade de apresentar documentos (..) e interpor recurso especial e extraordinário (...) na condição de terceiro interessado, bem como sustentar oralmente", diz ainda que "sempre que houver a regra da extensão subjetiva da coisa julgada para além do processo, deve haver alguma forma de controle da adequação do representante". (ROSA, 2013, p. 140). Contudo, a utilização do art. 543-C, CPC 1973 não costuma ser apontada com este problema típico, até porque não se perfaz coisa julgada: em última instância, é a aplicação de um precedente, e nesta seara não se fala em representatividade, não é um mecanismo de substituição processual.
} 
Revista Eletrônica de Direito Processual - REDP. Volume 16. Julho a dezembro de 2015

Periódico Semestral da Pós-Graduação Stricto Sensu em Direito Processual da UERJ

Patrono: José Carlos Barbosa Moreira. ISSN 1982-7636. pp. 240-281 http://www.e-publicacoes.uerj.br/index.php/redp/index

à qual haverá um procedimento apropriado que objetiva alcançar uma solução-padrão (...)

Mas também podemos cogitar em demandas de massa que envolvem interesses coletivos. Basta tomarmos o exemplo em que cada conselho de classe (ex. OAB/BA, OAB/SP, CREA/BA/, CREA/RJ etc) propõe uma ação questionando se as sociedades simples de profissionais que integram a respectiva categoria estão obrigadas a recolher certo tributo (ex. cofins). Elas possuem homogeneidade quanto a causa de pedir e quanto ao pedido. Por isso, estarão sujeitas ao regime dos processos repetitivos. Assim, podem ser julgadas conjuntamente; o Judiciário pode determinar o sobrestamento de todas elas, para que se faça o julgamento das que são consideradas paradigma (...) (BASTOS, 2010, p. 104).

\subsection{A aplicação da tese jurídica comum}

Permanece questionamento que o dispositivo não respondeu: aplicada a tese encontrada a partir do IRDR aos casos individuais, a resolução desta questão de direito se configura em coisa julgada?

Atualmente o art. 543-C, CPC/1973, tratando dos recursos repetitivos, se configura como um precedente não vinculante, de modo que o relator possa julgar sozinho a causa (art. 557, CPC /1973); seu correspondente no CPC/2015, dita que havendo recursos excepcionais repetitivos quanto à idêntica questão de direito, o presidente do Tribunal de Justiça ou Tribunal Regional Federal selecionarão causas-piloto, que serão julgadas pelo STJ ou STF, e então os juízes de primeiro grau deverão aplicar a tese fixada no recurso paradigma ${ }^{10}$, se isto não ocorrer será encaminhado o recurso especial ou extraordinário para o respectivo tribunal superior (art. 1041, §1 $\left.{ }^{\circ}, \mathrm{CPC} / 2015\right)$ ). Assim, a vinculação do julgamento repetitivo não é exercida nos mesmos moldes que no IRDR, pois desrespeitada a tese firmada no incidente, caberá Reclamação, seguindo então o sistema de inconformismo aplicável às

\footnotetext{
${ }^{10}$ Art. 1.040. Publicado o acórdão paradigma:

III - os processos suspensos em primeiro e segundo graus de jurisdição retomarão o curso para julgamento e aplicação da tese firmada pelo tribunal superior;
} 
Revista Eletrônica de Direito Processual - REDP. Volume 16. Julho a dezembro de 2015

Periódico Semestral da Pós-Graduação Stricto Sensu em Direito Processual da UERJ

Patrono: José Carlos Barbosa Moreira. ISSN 1982-7636. pp. 240-281 http://www.e-publicacoes.uerj.br/index.php/redp/index

sumulas vinculantes. Por esta razão já foi dito até que o incidente se aproximaria mais da ideia de uma "súmula vinculante em escala "local", limitada à competência do tribunal" (ROSA, 2013, p. 104; MOREIRA, 2014, p. 34), que do julgamento repetitivo de recursos excepcionais, por entender que a vinculação é mais forte, e seguir o mesmo sistema de Reclamação. O estudo tem apontado, contudo, que o incidente remonta sua origem e sua razão de ser ao julgamento repetitivo.

Além do mais, não há aqui a vinculação ocasionada pela súmula vinculante, que tem a aptidão de abarcar todos os órgãos jurisdicionais e todas as esferas e níveis da Administração Pública, de observação obrigatória. É o que diz o art. 103-A, CRFB. Também não é possível à súmula vinculante, ao contrário do que ocorre para o IRDR, sujeitar-se a revisão pelo STJ/STF por meio de recurso especial ou recurso extraordinário.

Neste ponto é preciso deixar claro que o art. 1036, CPC/2015 relativo aos recursos excepcionais repetitivos, o precedente é não vinculante, mas tem muita força: o precedente pode fazer com que a remessa necessária seja afastada, por exemplo, que o relator possa julgar sozinho ou que o juiz de primeiro grau possa inadmitir o recurso que não demonstre razões para ocorrer o distinguishing em relação ao precedente. O IRDR, presente no art. 976, CPC/2015 segue a mesma linha: na causa piloto haverá formação da coisa julgada material; já quanto aos processos que permaneceram suspensos, há a influência obrigatória do precedente formado, mas, ao contrário do que ocorre na formação da coisa julgada, sempre será possível o afastamento da aplicação do precedente que não se aplica ao caso ou que precisa ser superado.

\subsection{A distinção entre ação coletiva e o IRDR}

O instituto é novo e sua hipótese de incidência é algumas vezes confundida com a tutela coletiva:

Em termos genéricos, imagino que para a tutela de direitos difusos, a ação civil pública seja mais adequada, ao passo que na tutela dos direitos individuais homogêneos, o I.R.D.R (incidente de resolução de demandas repetitivas) seja mais apropriado. (PINHO, 2014, p. 202). 
Revista Eletrônica de Direito Processual - REDP. Volume 16. Julho a dezembro de 2015

Periódico Semestral da Pós-Graduação Stricto Sensu em Direito Processual da UERJ

Patrono: José Carlos Barbosa Moreira. ISSN 1982-7636. pp. 240-281 http://www.e-publicacoes.uerj.br/index.php/redp/index

Como visto, há autores que acabam analisando o instituto de resolução de demandas repetitivas como direitos coletivamente tratados, esquecendo-se que certos direitos que precisam de processo coletivo para que sejam justos, dependem da tutela coletiva para sua proteção. Na prática, existem dois tipos de direitos individuais homogêneos: os que só se realizam de fato em tutela coletiva ${ }^{11}$; e os que são repetitivos e tuteláveis em ações coletivas ou individuais, o que lhes reveste de um interesse metaindividual de que haja uma solução uniforme relativamente à questão comum que contém.

O autor citado imagina que se escolhe por coletivizar a demanda ou não, que o incidente seria uma alternativa à ação coletiva, o que não consiste numa leitura apurada dos dispositivos legais. Entendemos que não é uma escolha entre ação individual repetitiva e aplicação do incidente ou ação coletiva, porque mesmo para os direitos individuais homogêneos, como já foi demonstrado, não há escolha - ir por um ou outro caminho processual é questão de respeitar as particularidades do caso concreto.

A demanda será coletivizada, ou melhor, será criada nova demanda coletiva, quando se perceber que a ação é pseudoindividual, haja vista se tratar de um direito coletivo com aparência de direito individual, e os titulares precisarem, pelo caso concreto, de um legitimado extraordinário para defender o direito. Se, contudo, a demanda é repetitiva, já abarrotou o Judiciário e o problema diz respeito à administração deste volume de trabalho e controlar a uniformidade das decisões.

“(o incidente) não afastará a necessidade de adequada tutela coletiva no Brasil. Isso porque os objetivos perseguidos pelas ações coletivas são mais amplos que os almejados pela resolução de casos-piloto ou casos-teste. Como se viu, o incidente previsto no novo CPC tem por finalidade evitar a multiplicação de processos, proporcionando isonomia e segurança jurídica. Não está entre suas finalidades, todavia, promover o acesso à justiça, nem assegurar a tutela de direitos ontologicamente coletivos.” (ROQUE, 2013, p. 38)

\footnotetext{
${ }^{11}$ As ações coletivas permitem que um dano individual ínfimo, mas que coletivamente não se pode ignorar seja reparado, por exemplo.
} 
Revista Eletrônica de Direito Processual - REDP. Volume 16. Julho a dezembro de 2015

Periódico Semestral da Pós-Graduação Stricto Sensu em Direito Processual da UERJ

Patrono: José Carlos Barbosa Moreira. ISSN 1982-7636. pp. 240-281 http://www.e-publicacoes.uerj.br/index.php/redp/index

Isto porque o objetivo da ação coletiva é a tutela do direito transindividual, a ampliação do número de sujeitos com acesso, representados, na lide processual. O objetivo do incidente é promover a isonomia entre os jurisdicionados.

\section{TUTELA COLETIVA}

A tutela dos direitos supra-individuais tradicionalmente é realizada por substitutos processuais, pelo modelo de representatividade. Este modelo apresenta dificuldades e obstáculos práticos, principalmente quanto à vinculação de terceiros ao resultado do processo e sobre a partilha do ônus financeiro do processo entre seus beneficiados, isso por estarem dispersos no território e nem sempre têm conhecimento da demanda ajuizada em seu benefício. Os problemas relativos à legitimação extraordinária, extensão subjetiva da coisa julgada, repartição do ônus do processo e conhecimento da demanda pelos beneficiários são o calcanhar de Aquiles do sistema coletivo, como explica Cabral (2007, p. 107).

O tratamento dispensado a direitos repetidos foi se modificando - surge a ideia de "resolver coletivamente questões comuns a inúmeros processos em que se discutam pretensões isomórficas". (CABRAL, 2007, p. 107). Uma das soluções possíveis é a das causas piloto, como o previsto no art. 543-B, CPC 1973, já estudado.

As causas-piloto têm vantagens, porque preservam os princípios do processo individual e permitem simultaneamente que seja dado um tratamento coletivo, caracterizando-se pela ausência de um procedimento representativo, considerado desvantajoso no sistema romano-germânico.

O que se propõe então é a busca por algo similar a uma class action, mas sem a necessidade de se definir uma classe (...) o modelo alemão foi declaradamente adotado pelo nosso incidente de resolução de demandas repetitivas, que também adota um sistema não representativo para julgamento de tais demandas.

Em vez de se buscar uma adaptação do procedimento da ação civil pública (sistema de representatividade ou substituição processual), partiu-se para o objetivo de se reunir exclusivamente o julgamento das ações, mantendo tudo o mais separado, individual. 
Revista Eletrônica de Direito Processual - REDP. Volume 16. Julho a dezembro de 2015

Periódico Semestral da Pós-Graduação Stricto Sensu em Direito Processual da UERJ

Patrono: José Carlos Barbosa Moreira. ISSN 1982-7636. pp. 240-281 http://www.e-publicacoes.uerj.br/index.php/redp/index

Desta forma, não se coletiviza o processo, mantém-se a natureza individual das ações; não se impede o acesso ao judiciário, mas se moleculariza as ações. (ROSA, 2013, p. 128).

Por manter a natureza individual das ações é que é possível atingir a igualdade para os titulares de direitos semelhantes evitando os problemas próprios do sistema de substituição processual.

\subsection{Coisa julgada na tutela coletiva}

A coisa julgada só se caracteriza pela presença das mesmas partes, mesma causa de pedir e mesmo pedido, inviabilizando que se ingresse com uma outra ação que tenha essas mesmas características. Na esfera coletiva, a disciplina é dada pelo art. 103, CDC.

Nos dizeres de Grinover, a tutela coletiva encontra seus parâmetros de imutabilidade pautados pelos limites objetivos e subjetivos no art. 103, CDC:

(...) o art. 103 contém toda a disciplina da coisa julgada nas ações coletivas, seja definindo seus limites subjetivos (o que equivale a estabelecer quais entidades e pessoas que serão alcançadas pela autoridade da sentença passada em julgado), seja determinando a ampliação do objeto do processo da ação coletiva, mediante o transporte, in utilibus, do julgado coletivo às ações individuais. (GRINOVER, 2004, p. 904).

Gostaríamos muito que isso fosse verdade. Contudo, no art. 16, da Lei 7347/85, há a previsão de uma nova limitação, nunca dantes prevista nem aplicada para qualquer ação, de modo que nas ações coletivas, para definir o objeto da coisa julgada, observa-se: o objeto do julgamento, e os indivíduos sujeitos à imutabilidade, em dado território, ditado pela competência territorial do órgão prolator da decisão.

As regras relativas aos efeitos produzidos pela coisa julgada levam em consideração qual a natureza do direito discutido - se difuso, coletivo stricto sensu ou individual 
Revista Eletrônica de Direito Processual - REDP. Volume 16. Julho a dezembro de 2015

Periódico Semestral da Pós-Graduação Stricto Sensu em Direito Processual da UERJ

Patrono: José Carlos Barbosa Moreira. ISSN 1982-7636. pp. 240-281 http://www.e-publicacoes.uerj.br/index.php/redp/index

homogêneo, e também o resultado alcançado no processo, e a forma de impacto na esfera individual.

\subsection{Um direito para cada lugar?}

Tratando-se do art. 16, Lei 7347/85, o STJ já decidiu até por sua inaplicação, por entender que os efeitos erga omnes da sentença não podem ser restringidos territorialmente. Segue o julgado:

DIREITO PROCESSUAL. RECURSO REPRESENTATIVO DE CONTROVÉRSIA (ART. 543-C, CPC). DIREITOS METAINDIVIDUAIS. AÇÃO CIVIL PÚBLICA. APADECO X BANESTADO. EXPURGOS INFLACIONÁRIOS. EXECUÇÃO/LIQUIDAÇÃO INDIVIDUAL. FORO COMPETENTE. ALCANCE OBJETIVO E SUBJETIVO DOS EFEITOS DASENTENÇA COLETIVA. LIMITAÇÃO TERRITORIAL. IMPROPRIEDADE. REVISÃO JURISPRUDENCIAL. LIMITAÇÃO AOS ASSOCIADOS. INVIABILIDADE. OFENSA ÀCOISA JULGADA. 1. Para efeitos do art. 543-C do CPC: 1.1. A liquidação e a execução individual de sentença genérica proferida em ação civil coletiva pode ser ajuizada no foro do domicílio do beneficiário, porquanto os efeitos e a eficácia da sentença não estão circunscritos a lindes geográficos, mas aos limites objetivos e subjetivos do que foi decidido, levandose em conta, para tanto, sempre a extensão do dano e a qualidade dos interesses metaindividuais postos em juízo (arts. 468, 472 e 474,CPC e 93 e 103, CDC).1.2. A sentença genérica proferida na ação civil coletiva ajuizada pela Apadeco, que condenou o Banestado ao pagamento dos chamados expurgos inflacionários sobre cadernetas de poupança, dispôs que seus efeitos alcançariam todos os poupadores da instituição financeira do Estado do Paraná. Por isso descabe a alteração do seu alcance em sede de liquidação/execução 
Revista Eletrônica de Direito Processual - REDP. Volume 16. Julho a dezembro de 2015

Periódico Semestral da Pós-Graduação Stricto Sensu em Direito Processual da UERJ

Patrono: José Carlos Barbosa Moreira. ISSN 1982-7636. pp. 240-281 http://www.e-publicacoes.uerj.br/index.php/redp/index

individual, sob pena de vulneração da coisa julgada. Assim, não se aplica ao caso a limitação contida no art. $2^{\circ}$-A, caput, da Lei n. 9.494/97.2. Ressalva de fundamentação do Ministro Teori Albino Zavascki.3. Recurso especial parcialmente conhecido e não provido.

(STJ - REsp: 1243887 PR 2011/0053415-5, Relator: Ministro LUIS FELIPE SALOMÃO, Data de Julgamento: 19/10/2011, CE CORTE ESPECIAL, Data de Publicação: DJe 12/12/2011) (grifo nosso)

Nas palavras do relator, "o art. 16 da LACP baralha conceitos heterogêneos - como coisa julgada e competência territorial", porque leva a uma interpretação errônea de que os efeitos ou a eficácia da sentença possa ser limitada territorialmente, quando na verdade a coisa julgada não é a eficácia da sentença, mas qualidade que a ela se soma, revestindo seu conteúdo de imutabilidade e indiscutibilidade.

(...) a competência territorial limita o exercício da jurisdição e não os efeitos ou a eficácia da sentença, os quais, como é de conhecimento comum, correlacionam-se com os "limites da lide e das questões decididas" (art. 468, CPC)

A apontada limitação territorial dos efeitos da sentença não existe em nenhum tipo de processo, nem na demanda individual e, como mais razão, não pode ocorrer no processo coletivo, sob pena de desnaturação do mecanismo de solução plural das lides.

Esse regime processual não se justifica e esvazia a eficácia da tutela, o interesse acaba "privado de tutela judicial em sua dimensão coletiva, reconvertido e pulverizado em multifárias demandas individuais.” (MANCUSO, 2004, p. 403). Ainda, complete-se:

O dispositivo merece severas críticas. Primeiro, porque fraciona $o$ alcance das ações coletivas, estimulando a instauração de vários processos idênticos na hipótese de danos de âmbito regional ou nacional. Em um momento em que o processo civil está disposto a 
Revista Eletrônica de Direito Processual - REDP. Volume 16. Julho a dezembro de 2015

Periódico Semestral da Pós-Graduação Stricto Sensu em Direito Processual da UERJ

Patrono: José Carlos Barbosa Moreira. ISSN 1982-7636. pp. 240-281 http://www.e-publicacoes.uerj.br/index.php/redp/index

lançar mão até mesmo de súmulas vinculantes para lidar com o aumento da litigiosidade, tal medida parece na contramão da evolução do processo civil brasileiro. Além disso, a lei ignora que, quando o interesse for difuso ou coletivo stricto sensu, haverá indivisibilidade ontológica do objeto, não se admitindo por isso o fracionamento da tutela processual (grifo nosso) (ROQUE, 2013, p. 9).

Este sistema gera dois problemas principais: divide o alcance do objeto litigioso no território, pautado pela competência do órgão prolator, e consequentemente haverá processos idênticos com resultados distintos. É como se uma ação voltada à reparação de um dano em escala nacional fosse partida em várias outras, e não há controle sobre a uniformidade que as decisões deveriam ter, inclusive em atenção a ser o direito discutido transindividual. ${ }^{12} \mathrm{O}$ segundo problema é o de que o direito em si é incindível, e em direitos individuais homogêneos a necessidade de promover tutela coletiva, em virtude da superioridade das questões comuns e também sua prevalência sobre as questões particulares faz nascer o direito transindividual à resolução una da lide.

Sobre a proliferação das demandas repetitivas, a experiência de direito comparado sugeriria o julgamento de causas para além da competência territorial de um estado ou região da justiça federal. Sabiamente, no novo CPC é possível, após apreciação do STJ ou STF, a depender da matéria envolvida, que à tese firmada no incidente seja dada eficácia nacional.

"Esta via de uniformização nacional age de forma mais acertada que a limitação territorial vigente para ação civil pública, em que a coisa julgada tem limitação territorial à competência do juiz prolator da decisão, o que torna inócuo o instrumento de tutela coletiva.”(ROSA, 2013, p. 138). Assim, a aplicação do IRDR às demandas coletivas possibilita que a mesma tese jurídica geral, quanto a questão de direito, possa ser aplicada em todo o território nacional, abrangendo todo o dano causado.

Como dito por Roque (2013, p. 11), confundiu-se na feitura do art. 16, lei 7.347/85 competência e efeitos da coisa julgada, afrontando a jurisdição dos juízes, que tem o poder

\footnotetext{
12 Apesar da posição defendida pelo autor, este estudo se pauta pela diretriz de que todos os três direitos coletivos - difusos, coletivos stricto sensu e individuais homogêneos são direitos transindividuais.
} 
Revista Eletrônica de Direito Processual - REDP. Volume 16. Julho a dezembro de 2015

Periódico Semestral da Pós-Graduação Stricto Sensu em Direito Processual da UERJ

Patrono: José Carlos Barbosa Moreira. ISSN 1982-7636. pp. 240-281 http://www.e-publicacoes.uerj.br/index.php/redp/index

de dizer o direito para aquelas causas em qualquer extensão territorial em que os efeitos da sentença ocorram.

Ao deixar a decisão em aberto (se os legitimados extraordinários não ajuizarem em outras localidades, o direito ferido fica a descoberto, a despeito da decisão prolatada com efeito em certa região), deixa também o próprio conflito em aberto, de modo que a litigiosidade não é extinta.

"Jurisdição é a função do Estado de atuar a vontade concreta do direito objetivo" (CÂMARA, 2011, p. 73), marcada pela territorialidade, o que significa que os magistrados só tem autoridade nos limites territoriais do seu Estado: a jurisdição é exercida em certo território. Mas isto não vincula a produção de efeitos: a sentença produz efeitos em qualquer lugar que se faça necessária.

Não se pode confundir a territorialidade da jurisdição com o lugar onde a decisão irá produzir efeitos. A decisão judicial produzirá efeitos onde tiver de produzi-los: uma decisão brasileira pode produzir efeitos no Japão (...) uma decisão que determine que a União tome determinadas providências em aeroportos internacionais produzirá efeitos em todos os aeroportos internacionais do Brasil, e não somente naquele que esteja no território do juiz prolator da decisão. (DIDIER, 2010, p. 102)

Consiste em verdadeira violação da coisa julgada, pois, ao contrário da estabilidade que se busca atingir com a imutabilidade, cria oportunidades multiplicadas ao violador do direito se furtar a sua efetivação, possibilitando que um dano nacional ou regional seja reparado somente em certo estado, por exemplo. No fim das contas, o mesmo litígio é discutido várias vezes, em juízos distintos.

Em relação aos sujeitos do processo, o ordenamento quer evitar o constrangimento de um litigante ser submetido novamente à via crucis judicial pela mesma pretensão (...) função garantística da coisa julgada, destinada a não submeter o indivíduo duas vezes à mesma pretensão em juízo. (DIDIER, 2010, p. 103). 
Revista Eletrônica de Direito Processual - REDP. Volume 16. Julho a dezembro de 2015

Periódico Semestral da Pós-Graduação Stricto Sensu em Direito Processual da UERJ

Patrono: José Carlos Barbosa Moreira. ISSN 1982-7636. pp. 240-281 http://www.e-publicacoes.uerj.br/index.php/redp/index

O que dizer sobre submeter sujeitos que estariam adequadamente representados, numa ação que deveria ter abrangência nacional, mas que o ordenamento jurídico inadequadamente limitou a coisa julgada a um certo território? Terão estes titulares de direitos desacobertados que ajuizar nova ação e torcer para que atinja resultado idêntico a uma demanda idêntica em outro estado.

Além do mais, não há previsão legal de limitação territorial da produção de efeitos da decisão. Isto porque os parâmetros de aplicação são quanto à matéria (limite objetivo da coisa julgada - o que será tornado imutável) ou quanto aos sujeitos atingidos (quais sujeitos estão presentes no processo e se beneficiarão do pronunciamento jurisdicional).

Observe que a sistemática do art. 16, Lei 7347/85 viola a coisa julgada ao dar nova oportunidade de o sujeito passivo livrar-se da obrigação frente ao dano coletivo gerado, limitando a extensão do dano por uma razão injustificável: territorialidade. Sentença pronunciada contra uma empresa poluidora, por exemplo, deve atingir sua atividade de poluição onde quer que esteja. A benesse do dispositivo legal se configura como uma péssima escolha política que desestabiliza a coisa julgada. ${ }^{13}$

O espaço territorial só é importante para firmar a competência de quem vai julgar a lide, e não definir o alcance do julgamento, segundo Souza (2010, p. 3). A decisão deve ter eficácia até onde se revele a incidência do interesse objetivado, e por modo a se estender a todos os sujeitos concernentes, e isso, mesmo em face do caráter unitário desse tipo de interesse, que exige então uniformidade do pronunciamento judicial. ${ }^{14}$

Espera-se que a aplicação do incidente para as ações coletivas reflita uma tendência a corrigir os problemas do art. 16, LACP, voltando-se a doutrina e a jurisprudência à decisão una e uniforme. A jurisprudência mais recente do Superior Tribunal de Justiça se inclina no

\footnotetext{
13 “A imutabilidade é a impossibilidade de alteração do decisum e corresponde à imunização da decisão, isto é, sua blindagem de qualquer alteração posterior, seja por outro órgão do Judiciário, pelas partes ou ainda por atos de outros Poderes do Estado" (CABRAL, 2007, p. 54).

14 "Por exemplo, se o pedido numa ação civil pública em curso perante juiz competente (Lei 7.347/85, art. $2^{\circ}$, c/c CDC, art. 93) é que se interdite a fabricação de medicamento tido como nocivo à saúde humana, a resposta judiciária (inclusive como liminar) não pode, a nosso ver, sofrer condicionamento geográfico, seja porque não caberia falar numa 'saúde paulista', distinta de uma 'saúde gaúcha, seja porque, de outro modo, se teria que admitir a virtualidade de ação coletiva concomitante, em outra sede, ao risco da prolação de julgados porventura contraditórios, gerando caos e perplexidade. Ou, ainda, suponha-se uma ação civil pública ambiental onde se pede a interdição do uso de mercúrio no garimpo de ouro, atividade realizada ao longo de um rio que atravessa vários Estados: como a decisão judicial que acolhe a ação poderia ser realmente eficaz, se os seus efeitos práticos ficassem circunscritos em termos dos limites territoriais do Juízo prolator da decisão? (Nem por outro motivo, aliás, o art. 93 do CDC distingue entre 'dano nacional, regional e local'...)". (MANCUSO, 2004, p. 206).
} 
Revista Eletrônica de Direito Processual - REDP. Volume 16. Julho a dezembro de 2015

Periódico Semestral da Pós-Graduação Stricto Sensu em Direito Processual da UERJ

Patrono: José Carlos Barbosa Moreira. ISSN 1982-7636. pp. 240-281 http://www.e-publicacoes.uerj.br/index.php/redp/index

sentido de afastar a limitação imposta pelo dispositivo, e o desejado é que haja consolidação deste entendimento pelos próximos anos.

\subsection{Precedente $X$ Coisa julgada}

A valorização dos precedentes viabiliza a previsibilidade e continuidade do modo de compreender e afirmar o ordenamento jurídico, pela confiança gerada em virtude da expectativa de ter uma decisão num determinado sentido. Permite ao jurisdicionado prever as consequências jurídicas de seus atos.

As funções da coisa julgada e do precedente vinculante à luz da segurança jurídica e da tutela da confiança são distintas. $\mathrm{O}$ respeito aos precedentes garante a previsibilidade da ordem jurídica. A coisa julgada, por sua vez, garante que nenhuma decisão estatal interferirá de modo a inutilizar o resultado obtido pela parte com a decisão acobertada pela coisa julgada, assim como a estabilidade das decisões judiciais. (MARINONI et al, 2012, p. 441).

O precedente formado no incidente é bem mais forte que o instituto que lhe deu origem, o art. 543-C, CPC 1973, mas não chega a ser vinculante.

Então a coisa julgada tutela a confiança no ato estatal que decidiu o seu caso, assegurando que o benefício outorgado jamais lhe será retirado, que não será rediscutida a causa. Só pode ser desconstituída em hipóteses extremas, nunca em virtude de uma nova compreensão judicial sobre os fundamentos da decisão.

Diferenciam-se pela distinção entre os sujeitos que vincula: coisa julgada vincula as partes, e os precedentes são aplicados a terceiros alheios ao processo, e também pela aplicabilidade do precedente apenas a questões de direito, enquanto a coisa julgada engloba também os fatos.

Logicamente, a coisa julgada vincula e obriga as parte e tem mais força que o respeito aos precedentes. A estabilidade garantida pelos precedentes não é absoluta, já que os precedentes podem ser revogados, e afastados no caso concreto. "O judiciário pode deixar de interpretar a lei em determinado sentido, mas a interpretação da lei, cristalizada em 
Revista Eletrônica de Direito Processual - REDP. Volume 16. Julho a dezembro de 2015

Periódico Semestral da Pós-Graduação Stricto Sensu em Direito Processual da UERJ

Patrono: José Carlos Barbosa Moreira. ISSN 1982-7636. pp. 240-281 http://www.e-publicacoes.uerj.br/index.php/redp/index

sentença acobertada pela coisa julgada, jamais poderá ser alterada, de modo a roubar o benefício outorgado.” (MARINONI, 2012, p.443).

Vejamos: se um sujeito tem um processo em que se discute certa questão de direito repetitiva, e este é submetido ao incidente, após a decisão, deverá ser aplicada a tese jurídica firmada, mas o juiz poderá afastá-la se entender que as peculiaridades do caso justificam este posicionamento, e neste caso caberá reclamação ao STF. Se o sujeito tem uma ação individual que veicula direito coletivo, e opta por prosseguir nela, o julgamento da ação coletiva procedente pode ser aproveitado por este sujeito, que terá um título formado como seu, e lhe possibilitará fruir da efetivação do direito.

Rosa (2013, p. 139) traz o exemplo: ocorrendo dano por ação de uma empresa de telefonia fixa, que por erro desliga os telefones em vários estados, por 24 horas. Todos sofreram danos e devem ser reparados. Se cada morador ajuizasse ação individual, haveria milhões delas. Com a aplicação do incidente, teríamos a tese jurídica "quem desliga o telefone por erro deve indenizar" imposta a todos os processos, mas em cada um deles deverá ser feita prova do nexo causal (ser titular de linha telefônica) e prova do dano (telefone desligado por erro).

Assim, haveria certa possibilidade de o sujeito ser titular, não conseguir fazer a prova, e perder a tutela jurídica, por exemplo. Claramente a coisa julgada em ação coletiva seria mais vantajosa, pois já lhe entregaria o benefício. Mas deve-se lembrar que para os direitos repetitivos nem sempre podem ser protegidos em ação coletiva, de modo que a melhor proteção que têm no atual sistema processual é o de incidente de demandas repetitivas - que, se estendesse seu âmbito às questões de fato, abarcaria automaticamente todos os moradores, poupando-lhes das provas. Contudo, o legislador entendeu que incluir a possibilidade de incidente para questões de fato era ampliação difícil de controlar. Mas, por outro lado, como o tema é razoavelmente aberto, pode ser aplicado para outra operadora, que tenha também desligado o telefone por erro. Assim, a coisa julgada coletiva favorece a isonomia entre os envolvidos no mesmo evento, enquanto que a aplicação do incidente favorece isonomia geral, não necessariamente quanto ao mesmo evento, por se sobressair mais como norma abstrata.

\section{CONCLUSÃO}


Revista Eletrônica de Direito Processual - REDP. Volume 16. Julho a dezembro de 2015

Periódico Semestral da Pós-Graduação Stricto Sensu em Direito Processual da UERJ

Patrono: José Carlos Barbosa Moreira. ISSN 1982-7636. pp. 240-281 http://www.e-publicacoes.uerj.br/index.php/redp/index

O incidente de resolução de demandas repetitivas parece um mero incidente de julgamento repetitivo, como outros já inseridos em nosso ordenamento jurídico, mas tem implicações ainda melhores que o previsto. Ao estendê-lo para as ações coletivas, atinge-se maior justiça na decisão que está hoje restrita por limitações territoriais injustificáveis. Mas não se deve parar por aí: a forte estabilidade alcançada com a coisa julgada deve se estender a todo o direito coletivo julgado, independentemente de qualquer limite.

A proteção objetivada com o incidente não pode ser definida como tutela coletiva, tampouco como tutela individual. Diferente de uma tratativa coletiva de direitos, a demanda da vida concreta nos impulsionou à criação de uma terceira via de tratamento das ações, em que vários dos problemas da tutela coletiva não existem mais. Contudo, percebemos que a tese jurídica firmada pelo incidente não tem toda a força de coisa julgada, necessária ao processamento justo de certos direitos, resultado que só a tutela coletiva atinge, mas também com suas dificuldades.

O objeto do incidente são as demandas repetitivas, que se constituem nas situações homogêneas. Estas podem abarcar direitos individuais homogêneos ou não; no caso de a defesa do direito e a postulação em juízo ser acessível a grande parte dos titulares do direito envolvido, teremos demandas individuais repetitivas, que poderão ser submetidas ao incidente, mas também pode se referir a ações coletivas que sejam repetitivas, que neste caso veicularão direitos difusos, coletivos stricto sensu ou individuais homogêneos.

Não há que escolher se os direitos individuais homogêneos devem ser tratados pelo incidente ou pela ação coletiva, porque não se excluem. Deve ser proposta ação coletiva quando não houver repetição da demanda, pois há situações que por suas particularidades nunca serão pleiteadas em juízo pelos titulares, por uma relação de custo-benefício do processamento do direito - nestes casos a única possibilidade concreta de efetivação do direito será pela ação coletiva.

$\mathrm{O}$ instituto não se define muito bem nos conceitos conhecidos e delineados atualmente - o máximo que temos feito é classificá-lo como mecanismo de indução de precedentes. O que se sabe é que seus avanços são notórios e indicam uma nova direção para a solução das dificuldades que os operadores do direito enfrentam sempre - e que precisam ser revisitados, pensados, devem ser exatamente propostas soluções pois a crença no poder Judiciário e na justiça que realiza em muito se baseia nas noções de igualdade e celeridade. 
Revista Eletrônica de Direito Processual - REDP. Volume 16. Julho a dezembro de 2015

Periódico Semestral da Pós-Graduação Stricto Sensu em Direito Processual da UERJ

Patrono: José Carlos Barbosa Moreira. ISSN 1982-7636. pp. 240-281 http://www.e-publicacoes.uerj.br/index.php/redp/index

\section{REFERÊNCIAS BIBLIOGRÁFICAS:}

ALVES, Elaine Cristina Bueno. "Delineamento da Coisa Julgada e sua Garantia Constitucional”. Revista de Processo n. 827. São Paulo: RT, Set. 2004.

AMARAL, Guilherme Rizzo [et al]. "Efetividade, segurança, massificação e a proposta de um incidente de coletivização" in Processo Coletivo e outros temas de Direito Processual. Porto alegre: Livraria do Advogado editora, 2012, pp. 237-260.

ARRUDA ALVIM WAMBIER, Teresa; MEDEIROS, Maria Lúcia Lins Conceição. "Recursos repetitivos. Realização integral da finalidade do novo sistema impõe mais do que a paralisação dos recursos especiais que estão em $2^{\circ}$ grau" in Revista de Processo n. 191. São Paulo: RT, Jan. 2011, pp. 187-197.

BASTOS, Antonio Adonias Aguiar. "Situações jurídica homogêneas: um conceito necessário para o processamento das demandas de massa" in Revista de Processo n. 186. São Paulo: RT, Ago. 2010, pp. 97-104.

BRASIL. Exposição de motivos do novo Código de Processo Civil. Congresso Nacional. Senado Federal. Comissão de Juristas Responsável pela elaboração do Anteprojeto de Código de Processo Civil. Código de Processo Civil: anteprojeto/Comissão de Juristas responsável pela elaboração de Anteprojeto de Código de Processo Civil. Brasília: Senado Federal, Presidência, 2010.

BUENO, Cassio Scarpinella. Curso sistematizado de direito processual n. 5: recursos, processos e incidentes nos tribunais, sucedâneos recursais - técnicas de controle das decisões jurisdicionais. 3. ed. São Paulo: Saraiva, 2011.

CABRAL, Antonio do Passo. "O novo procedimento-modelo (Musterverfahren) alemão: uma alternativa às ações coletivas.” Revista de Processo n. 147. São Paulo: RT, Mai. 2007, pp. 124-146.

. Coisa julgada e preclusões dinâmicas - entre continuidade, mudança

e transição de posições processuais estáveis. 1. ed. Salvador: JusPodivm, 2013.

CÂMARA, Alexandre Freitas. Lições de direito processual civil, vol I. 21. ed. Rio de Janeiro: Lumen Juris, 2011.

CAPELlETTI, Mauro; GARTH, Bryant. Acesso à justiça. Tradução de Ellen Gracie Northfleet. Porto Alegre: Sergio A. Fabris, 1988. 
Revista Eletrônica de Direito Processual - REDP. Volume 16. Julho a dezembro de 2015

Periódico Semestral da Pós-Graduação Stricto Sensu em Direito Processual da UERJ

Patrono: José Carlos Barbosa Moreira. ISSN 1982-7636. pp. 240-281 http://www.e-publicacoes.uerj.br/index.php/redp/index

CINTRA, Antonio Carlos de Araújo; GRINOVER, Ada Pellegrini; DINAMARCO, CÂNDIDO Rangel. Teoria geral do processo. 14. ed. Brasil: Malheiros, 1998.

COSTA, Ivete Flávio; LASCALA, Maria Carolina Florentino, “a litispendência nas ações coletivas". Revista Eletrônica do Direito, v. 5, 2010, disponível em $<$ http://cascavel.cpd.ufsm.br/revistas/ojs-2.2.2/index.php/revistadireito/article/view/7057> acessado em 18/03/2015.

CUNHA, Leonardo Carneiro da. "O regime processual das causas repetitivas". Revista de Processo n. 179. São Paulo: RT, jan. 2010, pp. 139-174.

. "Anotações sobre o incidente de resolução de demandas repetitivas previsto no projeto do novo código de processo civil”. Revista de Processo n. 193. São Paulo: RT, Mar. 2011, pp. 256 - 279.

. "O processo civil no Estado constitucional e os fundamentos do projeto do novo código de processo civil brasileiro" in Revista de Processo n. 209. São Paulo: RT, Jul. 2012, pp. 350- 374.

DIDIER JR, Fredie; BRAGA, Paula Sarno; OLIVEIRA, Rafael Alexandria. Curso de direito processual civil - vol II. 8. ed. [S.1.]: Juspodivm, 2013.

DIDIER JR, Fredie; ZANETI JR, Hermes. Curso de direito processual civil - vol. IV: processo coletivo. 8. ed. [S.1.]: Juspodivm, 2013.

DIDIER JR, Fredie. Curso de Direito Processual Civil, vol. I: teoria geral do processo e processo de conhecimento. 12. ed. [S.1.]: Podivm, 2010.

FUX, Luiz. Palestra do VII Seminário Internacional Ítalo-Ibero-Brasileiro, realizado no Superior Tribunal de Justiça, dia 23/09/2010.

GRINOVER, Ada Pellegrini. Código Brasileiro de Defesa do Consumidor comentado pelos autores do anteprojeto. 8. ed. Rio de Janeiro: Forense, 2004.

" "Da class actions for damages à ação de classe brasileira: os requisitos de admissibilidade" in Revista de Processo n. 101. São Paulo: RT, Jan 2011, pp. 11-23.

LIEBMAN, Enrico Tullio. Eficácia e autoridade da sentença e outros escritos sobre a coisa julgada. Tradução: Alfredo Buzaid e Benvindo Aires. 4. ed. Rio de Janeiro: Forense, 2007.

LUSTOSA, Luis Geraldo Soares. Incidente de resolução de causas repetitivas: perspectivas econômicas implícitas na resolução de demandas repetitivas e de massa 
Revista Eletrônica de Direito Processual - REDP. Volume 16. Julho a dezembro de 2015

Periódico Semestral da Pós-Graduação Stricto Sensu em Direito Processual da UERJ

Patrono: José Carlos Barbosa Moreira. ISSN 1982-7636. pp. 240-281 http://www.e-publicacoes.uerj.br/index.php/redp/index

no projeto do novo Código de Processo Civil. 2012. 85f. Dissertação (Mestrado). Universidade Católica de Pernambuco, Recife/PE, 2012.

MANCUSO, Rodolfo. "Coisa julgada, collateral estoppel, e eficácia preclusiva secundum eventum litis”. Revista de Processo n. 608. São Paulo: RT, Jun. 1986. Ação civil pública. 9. ed. São Paulo: Revista dos Tribunais, 2004.

. A resolução de conflitos e a função judicial no Contemporâneo

Estado de Direito. 1. ed. São Paulo: Revista dos Tribunais, 2009.

MARINONI, Luiz Guilherme [et al], organizadores Araken de Assis, Carlos Alberto Molinaro, Luiz Manoel Gomes Junior, Mariângela Guerreiro Milhoranza. “Os precedentes na dimensão da segurança jurídica". Processo Coletivo e outros temas de direito processual. Porto Alegre: Livraria do Advogado Editora, 2012.

MENDES, Aluísio Azevedo de Castro; TEMER, Sofia. "O incidente de resolução de demandas repetitivas no novo Código de Processo Civil” in Revista de Processo n. 243. São Paulo: RT, mai. 2015, pp. 283-331.

MOREIRA, Thiego. Tutela coletiva de direitos individuais homogêneos e o incidente de resolução de demandas repetitivas: demandas seriais em perspectiva. 2014. $106 f$. Monografia para obtenção do título de Bacharel em Direito. Universidade Federal do Rio Grande do Norte, Natal, 2014.

NETO, Ney Castelo Branco. Primeiras impressões sobre o incidente de resolução de demandas repetitivas no projeto do novo CPC. Disponível em $<$ http://www.ambitojuridico.com.br/site/index.php?n_link=revista_artigos_leitura\&artigo_id=9463> acessado em $17 / 03 / 2015$

PINHO, Humberto Dalla Bernardina de. "Considerações sobre o incidente de conversão da ação individual em ação coletiva no projeto do novo CPC" in Revista Eletrônica de Direito Processual - ano 8, vol. XIV. Jul. 2014, pp. 195-212.

RODRIGUES, Roberto de Aragão Ribeiro [et al], coordenadores Andre Vasconcelos Roque e Humberto Dalla Bernardina de Pinho. O projeto do Novo Código de processo civil: uma análise crítica. 1. ed. Brasília, DF: Gazeta jurídica editora, 2013.

ROQUE, Andre Vasconcelos. “As ações coletivas no direito brasileiro contemporâneo: de onde viemos, onde estamos e para onde vamos?" in Revista Eletrônica de Direito Processual, vol. XII. Jul. 2013, pp. 36-65. 
Revista Eletrônica de Direito Processual - REDP. Volume 16. Julho a dezembro de 2015

Periódico Semestral da Pós-Graduação Stricto Sensu em Direito Processual da UERJ

Patrono: José Carlos Barbosa Moreira. ISSN 1982-7636. pp. 240-281 http://www.e-publicacoes.uerj.br/index.php/redp/index

ROSA, Renato Xavier da Silveira. Precedentes no processo civil brasileiro: valorização

e efetividade. 2013. 195f. Dissertação (Mestrado). Faculdade de Direito Largo São Francisco, São Paulo, 2013.

SEVERO, Álvaro Vinícius Paranhos. "A coisa julgada no processo coletivo" in Revista de

Direito e Justiça n. 39, Porto Alegre, Jul-Dez 2013, pp. 253-263.

SOUZA, Gelson Amaro de. "Coisa julgada e execução individual na ação coletiva”. Processos Coletivos, Porto Alegre, vol. 1, n. 4, 01 jul. 2010. Disponível em: $<$ http://www.processoscoletivos.com.br/ pcoletiv/component/jcomments/feed/com_conten t/109> Acesso em: 23/Mar/2015

TALAMINI, Eduardo. Partes, terceiros e coisa julgada: os limites subjetivos da coisa julgada. Aspectos polêmicos e atuais sobre terceiros no processo civil e assuntos afins. Freddie Didier Jr. e Teresa Arruda Alvim Wambier (coord.). São Paulo: RT, 2004.

VIDIGAL, Luís Eulálio de Bueno. Comentários ao Código de Processo Civil, v. VI. São Paulo: RT, 1976.

ZAVASCKI, Teori Albino. Processo coletivo: tutela coletiva de direitos e tutela de direitos coletivos. 2005. 295f. Tese de Doutorado. Universidade Federal do Rio Grande do Sul, Faculdade de Direito, Porto Alegre, 2005. 